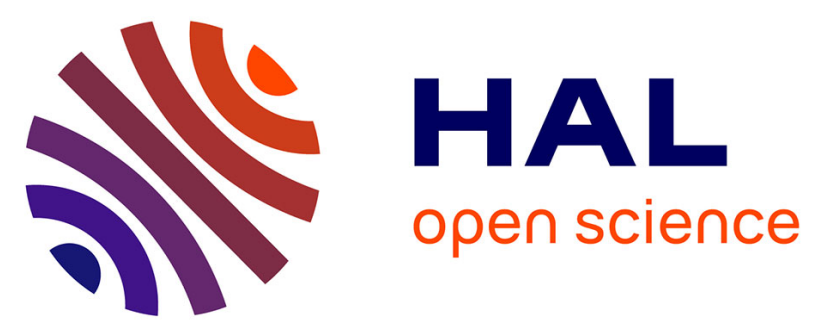

\title{
A simulation study of synergies and tradeoffs between multiple ecosystem services in apple orchards
}

Constance Demestihas, Daniel Plénet, Michel Génard, Christiane Raynal, Francoise Lescourret

\section{- To cite this version:}

Constance Demestihas, Daniel Plénet, Michel Génard, Christiane Raynal, Francoise Lescourret. A simulation study of synergies and tradeoffs between multiple ecosystem services in apple orchards. Journal of Environmental Management, 2019, 236, pp.1-16. 10.1016/j.jenvman.2019.01.073 . hal02625585

\section{HAL Id: hal-02625585 \\ https://hal.inrae.fr/hal-02625585}

Submitted on 21 Oct 2021

HAL is a multi-disciplinary open access archive for the deposit and dissemination of scientific research documents, whether they are published or not. The documents may come from teaching and research institutions in France or abroad, or from public or private research centers.
L'archive ouverte pluridisciplinaire HAL, est destinée au dépôt et à la diffusion de documents scientifiques de niveau recherche, publiés ou non, émanant des établissements d'enseignement et de recherche français ou étrangers, des laboratoires publics ou privés.

\section{(ㄷ)(1) $\$$}

Distributed under a Creative Commons Attribution - NonCommerciall 4.0 International 


\title{
A simulation study of synergies and tradeoffs between multiple ecosystem services in apple orchards
}

\author{
Constance Demestihas ${ }^{1,2}$, Daniel Plénet ${ }^{1}$, Michel Génard ${ }^{1}$, Christiane Raynal ${ }^{3}$, Françoise \\ Lescourret $^{1^{*}}$ \\ ${ }^{1}$ INRA, UR PSH 1115 (Plantes et Systèmes de cultures Horticoles), Centre de Recherche PACA, 228 route de \\ I'Aérodrome, CS 40509, Domaine Saint Paul, Site Agroparc, 84914 Avignon Cedex 9, France \\ ${ }^{2}$ CTIFL Centre de Saint-Rémy, Route de Mollégès, 13210 Saint-Rémy de Provence, France \\ ${ }^{3}$ CTIFL Centre de Lanxade, 8 Route des Nébouts, 24130 Prigonrieux, France \\ *francoise.lescourret@inra.fr
}

Abstract

In this study, we analyzed the patterns of relationships between multiple ecosystem services in apple orchards by considering the cascade that links agricultural practices to ecosystem functions and then to ecosystem services. Five major ecosystem services were considered: fruit production, soil nitrogen availability, climate regulation, water cycle maintenance and regulation, including water quality, and pest and disease control. We derived indicators of ecosystem functions and of ecosystem services from model simulations of orchards driven by virtual cropping systems combining various modalities of nitrogen fertilization, irrigation, and pest control. We deciphered the links between practices and ecosystem functions and between those functions and ecosystem services and clustered cropping systems according to their ecosystem service supply. Noticeable synergies were found between yield, fruit mass and sequestrated carbon. The contribution of carbon allocation to fruit in sequestrated carbon was considerable. Nitrogen absorption, impacted by fertilization and irrigation, was a major driver of these relationships. The typology built from these virtual cropping systems clearly followed 
a gradient of provisioning and regulating ecosystem services. Five cropping systems optimized the compromise between provisioning and regulating services and were essentially characterized by organo-mineral fertilization, comfort irrigation, apple scab-resistant cultivars and exclusion nets against codling moth.

Our approach could contribute to the design of cropping systems that would provide an acceptable compromise between multiple ecosystem services in orchards. 
1. Introduction

After the seminal works of Costanza et al. (1997) and Daily (1997) and the publication of the Millennium Ecosystem Assessment in 2005 (Reid et al., 2005), the ecosystem service concept has been expanding worldwide. The relationships between ecosystem services have been the subject of a growing number of studies (Cord et al., 2017) because their understanding is essential to the design of public policies and management strategies able to foster the sustainability of ecosystem service provision (Mouchet et al., 2014). There are both positive (synergies) and negative (tradeoffs) relationships between multiple ecosystem services, which arise from underlying ecosystem functions and/or management drivers (Bennett et al., 2009). As shown in the review of Lee and Lautenbach (2016), synergies are dominant between regulating or cultural services, and the relationships between regulating and provisioning services are dominated by tradeoffs. The minimization of tradeoffs is a key challenge of management policies (Rodríguez et al., 2006). As reported by Mouchet et al. (2014) and Cord et al. (2017), the analysis of ecosystem service relationships often includes the identification of ecosystem service bundles that can help link ecosystem management to desirable or undesirable sets of ecosystem services, following the pionneer work of Raudsepp-Hearne et al. (2010).

Landscape and regional scales are the most frequently considered scales in studies of patterns of ecosystem service relationships (Lee and Lautenbach, 2016; Finney et al., 2017), at the expense of smaller scales. In addition, causal relationships are often neglected (Cord et al., 2017) although a few authors have explicitly considered socio-cultural or environmental factors (Martin-Lopez et al., 2012; Renard et al., 2015; Meacham et al., 2016; Lamy et al., 2016; Feng et al., 2017). Ecosystem functions that contribute to services are rarely addressed in those studies (with the exception of Lavorel et al., 2011). Furthermore, ecosystem services are poorly quantified in many cases (Boerema et al., 2017) and there is a lack of use of models to address the issues of quantification and of relationships between services (Seppelt et al., 2011). Several studies of ecosystem service relationships have used 
models, but only to quantify the services (Nelson et al., 2009; Bai et al., 2011; Leh et al., 2013; Kragt and Robertson, 2014) rather than to highlight the ecosystem functions that underpin them. The models also have the advantage of making it possible to test a wide range of management scenarios in order to understand the effect of management on ecosystem service patterns, as shown in Kragt and Robertson (2014) and Zanchi et al. (2014).

Agroecosystems, beyond the food production service, may provide multiple non-marketed services such as soil structure and fertility, water quantity and quality, biological pest control, pollination and climate regulation through carbon sequestration and greenhouse gas (GHG) mitigation (Heal and Small, 2002; Swinton et al., 2007; Zhang et al., 2007; Power, 2010). The relationships between agroecosystem services are heavily impacted by agricultural practices as well as by pedoclimatic conditions, as reported by Power (2010) and exemplified by Kragt and Robertson (2014), Schipanski et al. (2014), Syswerda and Robertson (2014) and Finney et al. (2017). This is because, first, every service depends on many ecosystem functions, possibly in opposite ways, and, second, practices and pedoclimatic conditions have a strong influence on these functions, also possibly in opposite ways, as reported in the case of orchards (Demestihas et al., 2017). We are convinced that explicit consideration of the 'cascade' that links agricultural practices and pedoclimatic conditions to ecosystem functions and then to ecosystem services (see Gaba et al., 2015 and Demestihas et al., 2017, following Haines-Young and Potschin, 2009) can help us to understand the patterns of ecosystem service relationships in agroecosystems and to address the challenge of supporting regulating ecosystem services while maintaining or enhancing the provisioning services (Power, 2010).

To this day, there has been little focus on ecosystem services in fruit orchard research. However, orchards appear to be an interesting field of study because of the impact of their perennial character on biogeochemical cycles, their high potential in fruit production, and the importance of pest management practices, among other reasons (Demestihas et al., 2017 ; Simon et al., 2017). In this 
study, we analyzed, by means of model simulations, the patterns of relationships between multiple ecosystem services in the case of apple crops and at the orchard scale by considering the cascade that links agricultural practices to ecosystem functions and then to ecosystem services. We fixed the pedoclimatic conditions in order to focus on the role of agricultural practices. We also made a typology of simulated cropping systems according to their ecosystem service delivery, and identified cropping systems that optimize the compromise between provisioning and regulating services. We considered five important ecosystem services: fruit production, soil nitrogen availability, climate regulation, water cycle maintenance and regulation, including water quality, and pest and disease control. Together with these five services, we considered environmental disturbances due to pesticides. According to our cascade approach, we considered, based on the review of Demestihas et al. (2017), major ecosystem functions that underpin the selected ecosystem services, i.e., carbon, nitrogen and water balance processes, as well as pest damage and important agricultural practices that impact these functions, i.e., nitrogen fertilization, irrigation and the control of three main apple pests. Our expectation is that this study contributes to a better understanding of the functional and management bases of the relationships between ecosystem services in orchards, which is a prerequisite for the design of cropping systems that achieve desired profiles of ecosystem services.

2. Materials and methods

\subsection{General approach}

Figure 1 describes the general approach used in this study. Indicators of ecosystem functions and services (Section 2.2) were simulated on an annual time scale and at the spatial scale of the apple orchard plot based on the association of a crop model, STICS, and a model of crop injuries caused by pests, IPSIM (Section 2.3). Pedoclimatic data (temperature, humidity, radiation, potential evapotranspiration, rainfall and soil characteristics) and agricultural practices were inputs of the models. Model simulations used apple orchard cropping systems, i.e., combinations of agricultural practices, created in silico and based on different modalities of five agricultural practices - nitrogen 
fertilization, irrigation, and codling moth (Cydia pomonella), rosy apple aphid (Disaphis plantaginae) and apple scab (Venturia inaequalis) controls - in a given pedoclimatic context (Section 2.4). The model outputs, i.e., the indicators of ecosystem functions and services, were then analyzed using two principal component analyses with respect to instrumental variables (PCAIV) in order to formalize, on the one hand, the links between agricultural practices and ecosystem functions and, on the other, the links between ecosystem functions and ecosystem services. A typology of apple orchard cropping systems was then defined using hierarchical clustering and characterized in terms of ecosystem service profiles. This paved the way for an exploration of the optimal compromise between provisioning and regulating services among the cropping systems analyzed (Section 2.5).

Figure 1: Illustration of the general approach used for analyzing ecosystem service tradeoffs and synergies in apple orchards. Agricultural practices, ecosystem functions and ecosystem services are linked together through indicators, models (STICS, a crop model, and IPSIM, a model of crop injuries caused by pests) and data analysis tools.

\subsection{Ecosystem service and ecosystem function indicators}

Indicators describing ecosystem services are presented in Table 1. Soil nitrogen availability was described by two indicators: organic nitrogen variation, representing the level of organic nitrogen stocked (if positive) or destocked (if negative) within the soil profile every year, and the mean annual $\mathrm{NO}_{3}$ concentration in the first soil layer $(0-30 \mathrm{~cm})$. For climate regulation, we considered the mitigation of nitrous oxide $\left(\mathrm{N}_{2} \mathrm{O}\right)$ resulting from denitrification, as well as the mitigation of $\mathrm{CO}_{2}$ emissions from carbon sequestrated in the soil and the annual organs of trees. Sequestrated carbon includes the carbon stored in fruit. As reported in Demestihas et al. (2018), it is tailored to the annual time scale of the study during which fruit growth contributes to lower air $\mathrm{CO}_{2}$ concentration. It does not claim to represent the ability of the orchard to store carbon over the years, contrary to several studies of carbon budgets in orchards that consider fruit harvest as an export of carbon (e.g., 
Montanaro et al., 2017; Scandellari et al., 2016). The mitigation of nitrous oxide is referred to as "prevention of nitrogen denitrification" in Table 1. It was defined as the opposite of the yearly amount of denitrified nitrogen (i.e. minus this quantity that is intrinsically a disservice; Zhang et al., 2007): this way, a low level of the indicator indicates a low level of service. Water cycle maintenance and regulation, including water quality, was described by the water content in the soil, drainage and nitrate leaching prevention. The calculation of nitrate leaching prevention was similar to that of nitrogen denitrification prevention. Fruit production was described by gross yield and mean fresh fruit mass. Finally, we also considered the mitigation of environmental disturbances due to pesticides, and we used the reduction of the treatment frequency index, calculated in the same way as the prevention of nitrogen denitrification or of nitrate leaching, as a proxy. The pesticide treatments concerned only the three main apple pests, codling moth, rosy apple aphid and apple scab (see Section 2.3). Pest and disease control was not directly described by an indicator. It was implicitly considered through the fruit production indicators (yield and fruit mass) impacted by pest damage.

Indicators of ten ecosystem functions were proposed (Table 2). In soil, mineralization and leaching were described by the quantity of organic nitrogen transformed into mineral nitrogen ( $\mathrm{kg} \mathrm{N} \mathrm{ha}^{-1}$ year$\left.{ }^{1}\right)$ and the quantity of nitrogen leached in drained water over the year $\left(\mathrm{kg} \mathrm{NO}_{3}-\mathrm{N} \mathrm{ha}^{-1}\right.$ year $\left.{ }^{-1}\right)$. Humification corresponded to the carbon sequestrated in the soil organic matter in $\mathrm{kg} \mathrm{C} \mathrm{ha}^{-1} \mathrm{year}^{-1}$ (Saffih-Hdadi and Mary, 2008), while carbon sequestration was described by the carbon fixed yearly in the annual organs of the tree (fruits, leaves and stems). The two are related to the climate regulation service. Water use for fruit production was described by the mean value of all daily stomatic sufficiency indices from fruit set to harvest, ranging from 0 to 1,1 being the maximal comfort value. This index is the equivalent of relative transpiration, i.e., the ratio of actual transpiration to maximal transpiration (Brisson et al., 1998a). Nitrogen stress was described by a nitrogen nutrition index, also ranging from 0 to 1 , where 1 is the comfort value (Lemaire and Gastal, 1997). Nitrogen absorption by the tree was defined as the maximal quantity of nitrogen absorbed by 
fruits, leaves and stems on a yearly scale. Carbon allocation to fruits, which contributes to the fruit production service, was described by the quantity of carbon accumulated over a year in fruits, using fruit dry biomass at harvest, multiplied by the mean carbon content of fruits. For pest damage functions, fruit and leaf area losses were described by a percentage of fruit lost due to codling moth or apple scab, and a fraction of leaf area index (LAI) removed due to rosy apple aphid infestation, respectively.

\subsection{Models}

Two models were used to quantify ecosystem functions and service indicators.

The first model was STICS (Simulateur mulTIdisciplinaire pour les Cultures Standards), a soil-plant simulation model (Brisson et al., 2009, 1998b). STICS describes crop growth based on the development of a foliar surface that intercepts light and converts it into biomass that is allocated to roots and three aboveground annual organs: fruits, leaves and annual stems. STICS also describes water and nitrogen balances within the plant and soil compartments. Stress indices are calculated in water and nitrogen balance modules, reducing, if any, leaf growth and biomass accumulation. Inputs concern climate, soil and crop management, as well as nitrogen and water quantities in the soil and above and belowground biomass at the first date of the simulation. The model produces a considerable set of outputs that can be used as indicators of ecosystem functions and services. STICS is a widely used and robust generic model (Coucheney et al., 2015). It was successfully parameterized and evaluated on apple orchards using nine apple orchard systems located in southeastern France (northern and southern ends of this region: $44^{\circ} 58^{\prime} \mathrm{N}, 4^{\circ} 55^{\prime} \mathrm{E}$ and $43^{\circ} 43^{\prime} \mathrm{N}, 5^{\circ} 10^{\prime} \mathrm{E}$, respectively), which presented different climatic conditions, very contrasted soils and different types of agricultural management in terms of nitrogen fertilization, irrigation and planting density (Demestihas et al., 2018). We used the STICS model on an annual time scale.

IPSIM is an aggregative modeling framework that predicts injury profiles as a function of three factors: agricultural practices, abiotic environment - climate, in particular - and biotic environment - 
especially pest biological control potential (Aubertot and Robin, 2013). The model is based on a qualitative prioritization of these three factors, structured in a decision tree that enables the simulation of a damage profile on the considered crop for a given pest. IPSIM is implemented in DEXi software, a computer program for multi-attribute decision-making (Bohanec et al., 2004). It was parameterized on apple orchards for the three major apple pests: codling moth, rosy apple aphid and apple scab (Demestihas, 2017). The factors impacting these pest injuries were determined using a bibliographic study and experts' opinions. The model was successfully tested using the nine apple orchard systems used to evaluate the STICS model (see above; Demestihas, 2017). It is valid at least in the geographical region covered by the experts, southeast of France. The outputs of the model corresponded to a series (according to the IPSIM input factors) of mean quantitative values basically, ordinal values with expert-based quantitative correspondence - of pest injuries on either fruits or shoots. This led to a link with the functioning of the STICS model (Appendix 1). Rosy apple aphid injury was a percentage of daily leaf area loss, corresponding, in the STICS model, to leaf area removal from the peak of rosy apple aphid flight, i.e., in mid-May, to the tree's maximal leaf area establishment (mid-July). Apple scab injury on leaves was not taken into account. Injury levels due to codling moth and apple scab were percentages of marketable fruit loss. These two types of fruit loss, considered as two compatible and independent events, were combined into a general fruit loss percentage, which was simulated at harvest in the STICS model.

Appendix 1

\subsection{Designing virtual apple orchard cropping systems}

The pedoclimatic conditions were very close to the southernmost orchards used to validate the models (see 2.3). Climate characteristics were those of 2015 in Salon-de-Provence, France $\left(43^{\circ} 36^{\prime} \mathrm{N}\right.$, $5^{\circ} 7^{\prime}$ E). The climate was Mediterranean, with a mild winter (mean temperature between January and March of $8.5^{\circ} \mathrm{C}$ ), a hot and dry summer (mean maximal temperature in July of $32^{\circ} \mathrm{C}$, with $5 \mathrm{~mm}$ cumulated rainfall). Annual rainfall was $633 \mathrm{~mm}$. The actual mean daily evapotranspiration minus 
rainfall from April 1 to September 30 was $516 \mathrm{~mm}$. The soil was heavy with a clay loam texture (20\% clay), no pebbles, a pH of 8.5 and a nitrogen organic content in dry soil of $1 \mathrm{~g} \mathrm{~kg}$ of dry soil- ${ }^{-1}$ in the first soil layer. Soil bulk density was 1.3 , and the water field capacity was $25 \%$ of the soil dry mass, with an available water storage capacity of $98 \mathrm{~mm}$. The initial $\mathrm{C} / \mathrm{N}$ ratio of soil humus was fixed at 9.5. Soil depth was $60 \mathrm{~cm}$. The Golden Delicious cultivar was used, planted at a density of 2000 trees $\mathrm{ha}^{-1}$ without cover crops in the inter-row, the width of which was 4 meters. The maximal tree height was 3 meters. The crop load before fruit loss due to pests was 300 fruits per tree.

In order to create apple orchard cropping systems, we varied an array of five agricultural practices, while all the other management levers were considered to be fixed. We defined different modalities for nitrogen fertilization, irrigation, codling moth control, rosy apple aphid control and apple scab control (Table 3). Nitrogen fertilization was described by the combination of fertilizer type (mineral, organic or both) and quantity $\left(0,70\right.$ and $\left.140 \mathrm{~kg} \mathrm{~N} \mathrm{ha}^{-1}\right)$. Irrigation was triggered each time the stomatal water sufficiency index of the STICS model was under a specific threshold whose values were comfort (1), low water stress (0.7), high water stress (0.4) and no irrigation. For each pest control practice, a set of four to five modalities with different efficacies, plus a 'no protection' modality, were proposed (Beers et al., 2003; Grove et al., 2003; Holb, 2005; Laget et al., 2015). All pesticide applications were considered effective. The combinations of the modalities of the five practices defined the space of the possible virtual orchard cropping systems. Some constraints were imposed on these combinations for the sake of realism and to reduce their number in order to facilitate the interpretation of the results. Thus, it was not possible to have only one pest out of the three with no control (e.g., codling moth with no control and rosy apple aphid with chemical control and apple scab with cultivar resistance). In addition, it was not possible to combine biocontrol and chemical control for codling moth or for rosy apple aphid management. Out of the 1148 possible combinations, 150 cropping systems were randomly selected. The distribution of the different modalities of the agricultural practices in the 150 cropping systems is detailed in Appendix 2.

\subsection{Data analyses}


We performed $n=150$ simulations with the STICS model, corresponding to the 150 sampled cropping systems. Based on the results, we built three data tables, $X_{n p}, Y_{n q}$ and $Z_{n r} . X_{n p}$ contained $p=18$ variables that described the agricultural practices of the $\mathrm{n}$ simulated systems (Table 3, Appendix 2). Pest control practices were categorical $(0 / 1)$, whereas the quantitative variables related to both irrigation and fertilizer type were ordinal, i.e., 1 to 4 for irrigation (from no irrigation to hydrological comfort; see Table 3) and 1 to 2 for fertilizer quantities per fertilizer type. A 'No_ferti' categorical variable represented the cases where there was no fertilization (Table 3). $Y_{n q}$ contained $q=10$ variables that were the indicators of the ecosystem functions of the $n$ simulated systems (Table 2 ). $Z_{n r}$ contained $r=10$ variables that were the indicators of the ecosystem services of the $n$ simulated systems (Table 1).

Our analyses had two goals: finding patterns of covariation (i) between agricultural practices and ecosystem functions, and (ii) between ecosystem functions and ecosystem services. To achieve these goals, we used Principal Component Analysis with respect to Instrumental Variables (PCAIV; Sabatier et al., 1989), using the R package Ade4 (Dray and Dufour, 2007). PCAIV, also referred to as redundancy analysis or RDA (Dray et al., 2003), is particularly suitable for analyzing the relationships among response variables conditionally on explanatory ones. In this case, $\mathrm{Y}_{\mathrm{nq}}$ was analyzed conditionally on $X_{n p}$ and $Z_{n r}$ was then analyzed conditionally on $Y_{n q}$. As reported by Mouchet et al. (2014) and Cord et al. (2017), PCAIV/RDA has been frequently used to identify drivers that shape ecosystem service relationships (e.g., Martin-Lopez et al., 2012; Renard et al., 2015; Lamy et al., 2016; Meacham et al., 2016; Feng et al., 2017). PCAIV first performs multiple regressions of the $q$ variables of $Y$ on the $p$ variables of $X$. This results in a new data table $Y m$ of 'modeled' response variables. Ym represents the part of response variables linearly explained by the explanatory variables. Ym is then analyzed by a standardized principal component analysis (PCA). The solution of PCAIV is displayed in correlation plots where 'modeled' response variables and explanatory variables are represented by means of vectors whose cosines of angles are equivalent to correlations. The vectors with lengths close to one are the most important for the interpretation of the plane. PCAIVs 
were evaluated with the percentage of inertia (variation) of the table of the response variables explained by the table of the explanatory variables. This statistic is computed as 100 times the ratio of the sums of the eigenvalues of the PCAIV and of the PCA of the table of response variables and is referred to as $R^{2}$ since it is the multivariate equivalent of the regression coefficient of determination; its significance can be evaluated by randomly permuting the rows of the explanatory table (Thioulouse et al., 2018).

As reported by Cord et al. (2017), cluster analysis is widely used in the studies of ecosystem service relationships to identify types of service bundles. Examples can be found in Turner et al. (2014), Queiroz et al. (2015), Renard et al. (2015) and Lamy et al. (2016). In particular, agglomerative hierarchical clustering (AHC) has been successfully used in a study of service bundles in relation to socio-cultural factors (Martin Lopez et al., 2012). We used AHC to define a typology of cropping systems according to their ecosystem service delivery. AHC was performed on the 150 orchard cropping systems described by ten indicators of ecosystem services (Table $Z_{n r}$ mentioned above), with Ward's method and squared Euclidian distances (Everitt et al., 2011; Murtagh and Legendre, 2014). The average silhouette method (Rousseeuw, 1987) was used to determine the optimal number of clusters. The mean values of the ecosystem service indicators were calculated for each group defined from the AHC results, and normalized following Bradford and D'Amato (2012) and numerous studies of service bundles (e.g., Lu et al., 2014; Schipanski et al., 2014; Feng et al., 2017) as:

$$
\frac{e s-e s_{\min }}{e s_{\max }-e s_{\min }} \quad \text { Eq. } 1
$$

where $e s$ is the mean value of the service in the group and $e s_{\min }$ and $e s_{\max }$ are the minimal and maximal values of es over the groups defined from the AHC results. That way, a normalized value ranged from zero, the lowest level of es in the groups, to 1, the highest level. Ecosystem service profiles were represented by means of radar plots using these normalized values. Radar plots are very commonly used to illustrate ecosystem service bundles (Cord et al., 2017). 
In order to identify the cropping systems that optimized the compromise between provisioning and regulating services, the 150 cropping systems were plotted in a decision space represented by two criteria: the mean normalized value of provisioning ecosystem service indicators (i.e., yield and mean fruit mass) on the $y$-axis, and the mean normalized value of regulating ecosystem service indicators (i.e., all the other indicators) on the $\mathrm{x}$-axis. The normalization of each service followed the general principle of Eq. 1, where es was the value of the service for a cropping system and $e s_{\min }$ and $e s_{\max }$ the minimal and maximal values of this service over the 150 cropping systems. To evaluate the tradeoffs between these two criteria, we used the concept of Pareto-dominance that is commonly used in ecosystem service research (Groot and Rossing, 2011; Lafond et al., 2017; Sanon et al., 2012; Seppelt et al., 2013). For the cropping systems investigated, the set of 'non-dominated' tradeoffs, known as Pareto-optimal solutions, represented the best series of compromises across all criteria since no other cropping system is more effective when all of the services are considered. These tradeoffs can be quantified by their distance to the theoretical ideal solution (in which both criteria attain the maximal value).

3. Results

3.1 Agricultural practices heterogeneously impact ecosystem functions

The first PCAIV, applied on the 150 cropping systems, indicated that agricultural practices accounted for a large part of the variation of ecosystem function indicators $\left(R^{2}=83.7 \%, P<0.01\right)$. The first two principal components of the PCAIV explained $81.6 \%$ of the total variation (Figs. $2 A$ and B). Agricultural practices and ecosystem functions were well distributed on the PCAIV projection plane.

\subsubsection{Nitrogen- and water-related functions}

The first PCAIV factor was related to the intensity of irrigation and to the type of fertilization (Figs. 2A and B). The irrigation intensity (IRRI) ranged from 0 for no irrigation, to $500 \mathrm{~mm}^{-1}$ year $^{-1}$ for water comfort in the case of intensive orchard management. It had a considerable effect on water comfort 
(Appendix 3.A). The irrigation intensity was related to an increase in nitrogen mineralization

(Appendix 3.C) as well as a decrease in carbon sequestrated in the soil. These effects are due to the fact that the biological activity supporting soil nitrogen mineralization depends on soil moisture and that carbon sequestration in soil is antagonistic to nitrogen mineralization. The close proximity of carbon allocated to fruit and carbon sequestrated in the annual organs of the trees on the PCAIV plane was indicative of the large contribution of fruit to carbon sequestration in the tree. Nitrate leaching, carbon sequestration in annual organs, nitrogen absorption and the nitrogen nutrition index were all positively correlated to irrigation intensity and nitrogen fertilization gradients (Figs. 2A and B). However, the impact of irrigation on carbon sequestrated in the annual organs of trees (Appendix 3.B) seemed weaker than that of fertilization (Appendix 4.C). Fertilization impacted carbon sequestration in the annual organs, the nitrogen absorbed and the nitrogen nutrition index in a discontinuous way, with a jump between mineral and organo-mineral modalities that yielded higher values, and organic and 'no fertilization' modalities that yielded lower values (Appendices 4.A, B and C), but it increased nitrate leaching in a continuous way (Appendix 4.D). For intensively fertilized cropping systems (Min140), we observed a high variability of nitrate leaching quantities due to the combined effect of water and nitrogen inputs. In the Min140 cropping systems, low nitrate leaching values corresponded to the use of rain-proof covers for scab control, which prevented rainfall.

\subsubsection{Pest control-related functions}

The second component of the PCAIV plan was determined by pest control practices for the three pests (codling moth, rosy apple aphid and apple scab; Fig. 2). Chemical pest control and exclusion nets were negatively correlated with fruit and leaf area loss, whereas systems without pest protection showed high losses. Biological control lay between these two extreme situations. Codling moth and apple scab control modalities (except rain-proof cover against apple scab: SCcov) only affected fruit loss. It is interesting to note that SCcov was positively correlated on the first 
component of the PCA with the sequestration of carbon in the soil, probably because rain-proof covers prevent the supply of rainwater and decrease the soil water content.

The control of rosy apple aphid had an impact not only on leaf area loss but also on carbon sequestrated in annual organs. The effect is not visible when all cropping systems are considered, but it is clear that chemical control increased carbon sequestration on intensively fertilized and irrigated cropping systems, compared to oil or clay application and no control (Appendix 5). 
Figure 2: Correlation plots of explanatory variables, i.e., agricultural practices (A), and of response variables, i.e., ecosystem functions (B) with respect to the first two PCAIV components, PC1 (x-axis, 57.8\%) and PC2 (y-axis, 23.8\%). Abbreviations are defined in Tables 2 and 3. 
3.2 Ecosystem service patterns of correlations are explained by ecosystem functions

In the second PCAIV, ecosystem functions accounted for a major part of the ecosystem service variation $\left(\mathrm{R}^{2}=88.1 \%, \mathrm{P}<0.01\right)$ (Fig. 3). Components 1,2 and 3 explained $92 \%$ of the total variation. Ecosystem functions and ecosystem services were, like in the first PCAIV, well distributed on the PCAIV projection plane.

\subsubsection{Synergies}

Sequestrated carbon, yield and fruit mass were positively correlated (Fig. 3B). According to the PCAIV, these services were linked to carbon sequestration in the annual organs of the trees, most of which was allocated to fruits, the nitrogen nutrition index and nitrogen absorption (Fig. 3A). More specifically, yield and carbon sequestrated were multiplied by more than five when nitrogen

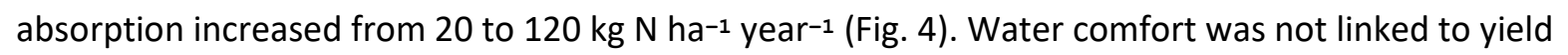
or fresh fruit mass.

According to the PCAIV results, drainage and mean soil humidity were positively correlated, probably due to their strong link to the water comfort function (Fig. 3 and Appendix 6). Water-related services have a specific status because they can impact other ecosystem functions. Water in soil impacts nitrogen mineralization by stimulating microbial activity, while it also contributes to the increase in the tree's water comfort level.

The service indicators $\mathrm{SoilNO}_{3}$ and VarNorg were positively correlated, without any clear explanation in terms of underlying functions, and the correlation was probably due instead to the type of soil.

\subsubsection{Tradeoffs}


Sequestrated carbon, yield and fruit mass were in conflict with the prevention of nitrogen

denitrification and of nitrate leaching due to two positively correlated ecosystem functions: nitrogen absorption and nitrate leaching (Fig. 3 and Appendix 6).

The service indicators for the prevention of nitrate leaching and soil nitrate concentration were logically negatively correlated (Fig. 3). More interestingly, organic nitrogen variation was negatively correlated to water-related services (mean soil humidity and drainage; Fig. 3B). This negative correlation can be explained by a key function: nitrogen mineralization (Fig. 3A). Water increases nitrogen mineralization values, and more mineralization implies less organic nitrogen variation. Furthermore, since carbon and nitrogen sequestration go hand-in-hand, carbon sequestration in the soil was at the exact opposite of nitrogen mineralization on the PCAIV plane (Fig. 3A).

Pest-related variables (i.e., fruit and foliar surface loss for ecosystem functions, TFI reduction for response variables) were accounted for on the third component (Appendix 6). Yield was negatively correlated to TFI reduction. Fruit and leaf area losses were positively correlated to TFI reduction, suggesting that in the conditions of the simulations, a reduction of pesticide use was not actually compatible with efficient pest control. 
Figure 3: Correlation plots of explanatory variables, i.e., ecosystem functions (A), and of response variables, i.e., ecosystem services (B) with respect to the first two PCAIV components, PC1 (x-axis, 51.5\%) and PC2 (y-axis, 32.4\%). Abbreviations are defined in Tables 1 and 2.

Figure 4: Relationships between nitrogen absorbed (function indicator) and yield, fruit mass and sequestrated carbon (service indicators). Lines represent linear regressions. 
3.3. Typology of apple orchard cropping systems: a tradeoff between provisioning and regulating ecosystem services

Five groups were defined based on the AHC of the 150 cropping systems described by the indicators of ten ecosystem services and the use of the average silhouette approach. The five groups were well distributed on the first plane of the second PCAIV (i.e., linking ecosystem functions to services), mostly on the first component corresponding to the conflict between yield, fruit mass and sequestrated carbon, on the one hand, and the prevention of nitrogen denitrification on the other (Fig. 5). However, group 4 had higher scores than the other groups on the second component because of lower values of organic nitrogen variation and of soil nitrate concentration, and of higher values of prevention of nitrate leaching (Fig. 5). A detailed description of the agricultural practices in each group is given in Table 4. The ecosystem service profiles of the five groups are described in Table 5 and on the radar plots of Fig. 6. Globally, the average of normalized values of all ecosystem services taken together was the highest for group 1 (0.611) and the lowest for group 5 (0.392), groups 2,3 and 4 being intermediate $(0.532,0.545$ and 0.476 , respectively).

The first group included 14 cropping systems. Yield, fruit mass and sequestrated carbon reached very high values in this group. Intensive leaching reduced the ability to maintain water quality. Irrigation was conducted in water comfort mode, creating higher mineralization and, consequently, a higher level of destocked organic nitrogen. Chemical pesticides were used to control codling moth and rosy apple aphid, which explained the low value of TFIreduc.

Group 2 included 28 cropping systems. A part of the cropping systems used $140 \mathrm{~kg} \mathrm{ha}^{-1} \mathrm{year}^{-1}$ of mineral fertilizers and water comfort for irrigation. This created high mean nitrate concentrations in the soil. However, since some of the group's cropping systems used organo-mineral fertilization and had low water stress, organic nitrogen and the prevention of nitrogen denitrification increased compared to group 1, whereas yield, carbon sequestrated and fruit mass decreased. TFIreduc was 
low in group 2 despite the use of exclusion nets against the codling moth and biocontrol against the rosy apple aphid because of a chemical control of apple scab.

Group 3 included 37 cropping systems that were close to the center of the PCAIV projection plane, thus corresponding to the minimal conflict between all ecosystem services. Fertilization was mineral or organo-mineral in this group, with a balanced distribution between the four modalities. This may be an explanation for increased prevention of nitrogen denitrification compared to the previous groups. The soil nitrate concentration was surprisingly high in these cropping systems, which could be explained by the reduced production of annual organs and a resulting decrease in nitrogen absorption. That could be the reason why nitrate leaching was maintained relatively high $(39.6 \mathrm{mg}$ $\mathrm{NO}_{3} \mathrm{I}^{-1}$ drained water). Most of these cropping systems were either not irrigated or submitted to conditions of high water stress. Compared to the previous groups, this could have contributed to decreased nitrogen denitrification as well as yield, fruit mass and sequestrated carbon. Yield was also impacted by the predominant 'No control' modality for codling moth and rosy apple aphid control, which also increased TFlreduc compared to groups 1 and 2.

Group 4 included 48 more unconventional cropping systems that globally increased nitrogen denitrification and nitrate leaching prevention services, whereas soil nitrate concentration, yield, fruit mass and sequestrated carbon were low. The major reason is that fertilization was absent or organic with low bioavailabilty in these systems. TFIreduc was high in this group where the use of exclusion nets against the codling moth was dominant and the distribution of the other control modalities was fairly balanced for all three pests.

Group 5 included 23 unconventional cropping systems. Yield, fruit mass and sequestrated carbon were the lowest of all groups. Fertilization was mainly organic or absent and, accordingly, the prevention of nitrogen denitrification was similar to that in Group 4. Most importantly, water stress prevailed in these cropping systems, either with low or no irrigation inputs or due to cover nets for apple scab control (which prevented rainfall), or with the combination of both of these practices 
(represented in the lower right part of Fig. 5). Thus, the levels of the water-related services, mean soil humidity and drainage were the lowest of all the groups, and organic nitrogen variation, in conflict with these services (Section 3.2.2), was high. TFIreduc was high in this group where the use of rain-proof covers against apple scab was predominant and the distribution of the control modalities regarding codling moth and rosy apple was fairly balanced.

Five cropping systems optimized the compromise between provisioning and regulating services (Fig. 7). The shortest distance from a theoretical ideal solution was attributed to one cropping system that used mineral fertilization with $70 \mathrm{~kg} \mathrm{~N} \mathrm{ha}^{-1} \mathrm{year}^{-1}$, comfort irrigation, chemical control for codling moth and rosy apple aphid, and an apple scab-resistant cultivar. The four other cropping systems used organo-mineral fertilization with $140 \mathrm{~kg} \mathrm{~N} \mathrm{ha}^{-1} \mathrm{year}^{-1}$ (3) or mineral fertilization with $70 \mathrm{~kg} \mathrm{~N} \mathrm{ha}^{-1}$ year $^{-1}(1)$, comfort irrigation, exclusion nets (3) or chemical control (1) against codling moth, and an apple scab-resistant cultivar. All cropping systems belonged to group 1. Their ecosystem profiles are shown in Appendix 7.

Figure 5: Five groups of apple orchard cropping systems projected on the two first components of the PCAIV of ecosystem functions and services.

Figure 6: Profiles of ecosystem services of the five groups of apple orchard cropping systems on radar plots. Abbreviations are defined in Table 1.

Figure 7: Tradeoffs between provisioning ecosystem services, i.e., yield and fruit mass, and regulating services, i.e., soil nitrogen availability, climate regulation, hydrological cycle maintenance and regulation and reduction of environmental disturbances due to pesticides. Each point or number represents a cropping system. The double-arrowed cropping systems represent the highest performances for provisioning services and for regulating services, respectively. Cropping systems 
represented by numbers are those that optimize the compromise between provisioning and regulating services. Dotted lines are the distances from a theoretical ideal solution.

4. Discussion and conclusions

4.1. Main achievements and limits

Our simulation study demonstrated the strength of the links between agricultural practices, ecosystem functions and the resulting patterns of relationships between ecosystem services in apple orchards. It seemed that nitrogen fertilization, often interacting with irrigation, was the agricultural practice with the greatest impact since most of the ecosystem services considered were linked to nitrogen. Nitrogen fertilization has also been identified as one of the most important determinants of the delivery of multiple agroecosystem services in a study conducted along a gradient of cropping systems (Syswerda and Robertson, 2014). In the range of studied cropping systems, observable synergies were found between yield, fruit mass and sequestrated carbon. The contribution of carbon allocation to fruit in sequestrated carbon at the annual scale was considerable, and this is clearly a specificity of orchards compared to other ecosystems. These services were in conflict with the prevention of nitrogen denitrification and leaching, also reported by Syswerda and Robertson (2014). Nitrogen absorption, which is impacted by fertilization and irrigation, was a major driver of these relationships. Water supply appeared to impact ecosystem functions such as nitrogen mineralization (De Neve and Hofman, 2002), and the resulting services such as organic nitrogen variation. The functions related to pest and disease control only contributed to yield. Consequently, they were poorly represented on the first plane of the second PCAIV (linking ecosystem functions to ecosystem services). It can be observed that practices that impact many functions are more likely to reveal tradeoffs or synergies between services. For example, irrigation influences a wide range of services by its actions on ecosystem functions of the nitrogen cycle (nitrogen mineralization, denitrification, nitrate leaching) and of the water cycle (runoff, infiltration, evapotranspiration, water allocation to 
tree organs), as shown here and reported by Demestihas et al. (2017). It also influences pest regulation through the modification of the physical or chemical dimension of the ecological niche of pests (e.g., Gibert et al., 2007; Gibert et al., 2009; Rousselin et al., 2018). Other practices investigated in studies of bundles of agroecosystem services have similar multiple actions on ecosystem functions and positive effects on a large range of services, such as the use of cover crops in annual crops (Schipanski et al., 2014) or that of shade trees in coffee agroecosystems (Meylan et al., 2017).

With the exception of a synergy between sequestrated carbon and yield or fruit mass characteristic of orchards (see above), our study showed tradeoffs between provisioning and regulating ecosystem services. The five groups of apple orchard cropping systems described by ten ecosystem services were distributed on a gradient expressing this tradeoff. This confirms a general trend, observed at large scales (see Introduction) and at the scale of plots in agroecosystems (Syswerda and Robertson, 2014; Kragt and Robertson, 2014; Rapidel et al., 2015).

However, we found five non-dominated cropping systems that optimized both provisioning and regulating services. Management options can be found that correspond to acceptable compromises between agroecosystem services (Power, 2010; Kragt and Robertson, 2014; Finney et al., 2017). In our study, the five non-dominated cropping systems were obtained using two very simple criteria. However, these criteria were calculated considering the same weight for each service, whereas each service weight should be discussed with experts in order to more clearly differentiate between different types of criteria that enable multiple ecosystem service optimization.

The simulations were based on two models adapted to apple orchards, STICS and IPSIM. For STICS, this adaptation relied on the estimation of some parameters using data from apple orchards located in southeastern France. Even though more experimental data would be necessary to consolidate this adaptation, we are confident in the fact that its domain of validity exceeds this area, as discussed in depth in Demestihas et al. (2018). On the one hand, STICS was proven to be accurate and robust in a wide range of agropedoclimatic conditions (Coucheney et al., 2015). This robustness of the STICS 
model has enabled it to be used under very diverse conditions, sometimes on a very large scale, as in the study of the impact of climate change on viticulture on a European scale (Fraga et al., 2016). On the other hand, a thorough comparison of the simulated values of ecosystem functions and services to literature values, e.g. LAl, nitrate concentration and humidity in soil, emissions of $\mathrm{N}_{2} \mathrm{O}$, allowed us to be confident in the capacity of the model to support ecosystem services analysis (Demestihas et al., 2018). Important limits concerning the time scale of the study can be emphasized. Since we simulated crop functioning over a single year, no organic matter was returned to the soil, which explains why the organic nitrogen variation remained negative. On a long-term perspective, fresh organic matter returned to the soil from cover crops or crop residues could significantly increase the soil organic nitrogen stock from one year to another (Strullu et al., 2014). The relationship between water regulation and organic nitrogen variation should therefore change when operating multi-year simulations. Moreover, since simulations took place on bare soil conditions, this may have increased nitrogen denitrification and leaching values. Further research is needed on the functioning of apple orchard cover crops in order to adapt the intercropping module of STICS used for annual crops to this case (Brisson et al., 2004). In addition, nitrogen reserve remobilization from the structural parts of the tree was not considered, increasing the dependence of fruit production and of carbon sequestration in the annual organs of the trees on nitrogen absorption.

Regarding IPSIM, the adaptation of the modelling framework to apple orchards was valid at least in the geographical region of the experts and of the dataset used for the test, southeast of France. The simulations studied here used the climatic conditions of the southernmost orchards of this dataset. A larger database outside this region would be necessary to evaluate the predictive quality of the model. If the results were not satisfactory, a further adaptation would be necessary, knowing that the modelling framework is generic per se. In addition, coupling the crop-soil functions described in STICS and the pest damage described in IPSIM has been one of the main difficulties of this study since IPSIM is not a dynamic and mechanistic model, contrary to STICS. Thus, the pest damage was considered globally (e.g., fruit loss due to apple scab or codling moth was considered at harvest and 
not during the growing season), as was the effect of pest control practices. Moreover, the IPSIM model is based on a weighting system of factor effects on pest damage. Given the present state of knowledge and the high pest pressure used in the simulations, chemical and integrated pest control had a much greater effect on pest and disease control in the broad sense than biological control, i.e., that provided by the planned and/or spontaneous biodiversity.

\subsection{Advantages of our approach}

In our study, three innovative key features stand out, partially addressing the criticisms made by Seppelt et al. (2011) of the current research in ecosystem service analysis.

The first feature was to analyze synergies and tradeoffs in multiple ecosystem services, which is common in general studies at regional or landscape scales but less common in agroecosystem studies on smaller scales. In particular, as shown in the review of Rapidel et al. (2015), most studies on perennial crops have focused on two-way service relationships, considering a provisioning service and a regulating service: for example, grapevine yield and fungal disease regulation (Guilpart et al., 2017), grapevine yield and runoff mitigation (Ripoche et al., 2011) or fruit production and biodiversity conservation (Baumgärtner and Bieri, 2006). Small-scale modeling or experimental studies of relationships among multiple agroecosystem services, including provisioning services and a whole array of regulating services, are still scarce (Kragt and Robertson, 2014; Robertson et al., 2009; Syswerda and Robertson, 2014, Finney et al., 2017). Unlike some of them that include different agroecosystems, our study focused on a particular agroecosystem - the apple orchard - thus placing greater emphasis on the comparison of specific types of apple orchard management.

The second feature was to link ecosystem functions to ecosystem service indicators using models. Models make it possible to describe and quantify the relationships between functions and between functions and services. In this study, they provided a clear picture of ecosystem service 
interdependency based on feedback loops and interactions between ecosystem functions, as already demonstrated with the APSIM model by Kragt and Robertson (2014).

The third and last feature was the use of a wide range of cropping system situations. This enabled us to connect types of cropping systems and profiles of ecosystem services, as well as to identify cropping systems that provide a good compromise between provisioning and regulating ecosystem services. Rapidel et al. (2015) stressed the importance of making farmers aware of the possibilities of combining the best sets of practices to provide the desired combinations of ecosystem services. The space of possibilities in terms of cropping systems could be expanded and its exploration could be facilitated by using multi-objective optimization procedures (Grechi et al., 2012; Ould-Sidi and Lescourret, 2011).

\section{Acknowledgements}

This work was funded by an industrial training agreement through a CIFRE research fellowship from the CTIFL (Centre Technique Interprofessionnel des Fruits et Légumes) and the ANRT (Association Nationale de la Recherche et de la Technologie) on behalf of the French Ministry of Higher Education and Research. We would like to thank Dominique Grasselly (CTIFL) for his support and two anonymous reviewers for their valuable comments.

\section{References}

Aubertot, J., Robin, M., 2013. Injury Profile SIMulator, a qualitative aggregative modelling framework to predict crop injury profile as a function of cropping practices, and the abiotic and biotic environment. I. Conceptual bases. PLoS One 8. doi:10.1371/journal.pone.0073202

Bai, Y., Zhuang, C.W., Ouyang, Z.Y., Zheng, H., Jiang, B., 2011. Spatial characteristics between biodiversity and ecosystem services in a human-dominated watershed. Ecol. Complex. 8, 177183. 
Baumgärtner, J., Bieri, M., 2006. Fruit tree ecosystem service provision and enhancement. Ecol. Eng. 27, 118-123. doi:10.1016/j.ecoleng.2005.12.005

Beers, E.H., Suckling, D.M., Prokopy, R.J., Avilla, J., 2003. Ecology and management of apple arthropod pests., in: Ferree, D.., Warrington, I.J. (Eds.), Apples: Botany, Production and Uses. CABI, Wallingford, pp. 489-519. doi:10.1079/9780851995922.0489

Bennett, E.M., Peterson, G.D., Gordon, L.J., 2009. Understanding relationships among multiple ecosystem services. Ecol. Lett. 12, 1394-1404. doi:10.1111/j.1461-0248.2009.01387.x

Boerema, A., Rebelo, A.J., Bodi, M.B., Esler, K.J., Meire, P., 2017. Are ecosystem services adequately quantified? J. Appl. Ecol. 54, 358-370.

Bohanec, M., Džeroski, S., Žnidaršic, M., Messéan, A., Scatasta, S., Wesseler, J., 2004. Multi-attribute modelling of economic and ecological impacts of cropping systems. Informatica 28, 387-392.

Bradford, J.B., D'Amato, A.W., 2012. Recognizing trade-offs in multi-objective land management. Front. Ecol. Environ. 10, 210-216.

Brisson, N., Bussière, F., Ozier-Lafontaine, H., Tournebize, R., Sinoquet, H., 2004. Adaptation of the crop model STICS to intercropping. Theoretical basis and parameterisation. Agronomie $24,409-$ 421. doi:10.1051/agro

Brisson, N., Itier, B., L'Hotel, J., Lorendeau, J., 1998a. Parameterisation of the Shuttleworth-Wallace model to estimate daily maximum transpiration for use in crop models. Ecol. Modell. 107, 159169. doi:10.1016/S0304-3800(97)00215-9

Brisson, N., Launay, M., Mary, B., Beaudoin, N., 2009. Conceptual basis, formalisations and parameterization of the STICS crop model. Editions QUAE, Paris.

Brisson, N., Mary, B., Ripoche, D., Jeuffroy, M., Ruget, F., Nicoullaud, B., Gate, P., Devienne-Barret, F., Antonioletti, R., Durr, C., Guy, R., Beaudoin, N., Recous, S., Tayot, X., Plenet, D., Cellier, P., Machet, J.-M., Meynard, J.-M., Delécolle, R., 1998b. STICS: a generic model for the simulation of 
crops and their water and nitrogen balances. I. Theory and parameterization applied to wheat and corn. Agronomie 18, 311-346.

Cord, A.F., Bartkowski, B., Beckmann, M., Dittrich, A., Hermans-Neumann, K., Kaim, A., Lienhoop, N., Locher-Krause, K., Priess, J., Schroter-Schlaack, C., Schwarz, N., Seppelt, R., Strauch, M., Vaclavik, T., Volk, M., 2017. Towards systematic analyses of ecosystem service trade-offs and synergies: Main concepts, methods and the road ahead. Ecosystem Services 28, 264-272.

Costanza, R., d’Arge, R., deGroot, R., Farber, S., Grasso, M., Hannon, B., Limburg, K., Naeem, S., Oneill, R.V., Paruelo, J., Raskin, R.G., Sutton, P., vandenBelt, M., 1997. The value of the world's ecosystem services and natural capital. Nature 387, 253-260.

Coucheney, E., Buis, S., Launay, M., Constantin, J., Mary, B., de Cortazar-Atauri, I.G., Ripoche, D., Beaudoin, N., Ruget, F., Andrianarisoa, K.S., Le Bas, C., Justes, E., Leonard, J., 2015. Accuracy, robustness and behavior of the STICS soil-crop model for plant, water and nitrogen outputs: Evaluation over a wide range of agro-environmental conditions in France. Environ. Model. Software $64,177-190$.

Daily, G., 1997. Nature's services. Societal dependence on natural ecosystems. Island Press, Washington DC.

De Neve, S., Hofman, G., 2002. Quantifying soil water effects on nitrogen mineralization from soil organic matter and from fresh crop residues. Biol. Fertil. Soils 35, 379-386. doi:10.1007/s00374-002-0483-3

Demestihas, C., 2017. Analyse des conflits et synergies entre services écosystémiques multiples en vergers de pommiers. PhD. Université d'Avignon et des Pays du Vaucluse.

Demestihas, C., Plénet, D., Génard, M., Garcia de Cortazar-Atauri, I., Launay, M., Ripoche, D., Beaudoin, N., Simon, S., Charreyron, M., Raynal, C., Lescourret, F., 2018. Analyzing ecosystem services in apple orchards using the STICS model. Eur. J. Agron. 94, 108-119. 
doi:10.1016/j.eja.2018.01.009

Demestihas, C., Plénet, D., Génard, M., Raynal, C., Lescourret, F., 2017. Ecosystem services in orchards. A review. Agron. Sustain. Dev. 37. doi:10.1007/s13593-017-0422-1

Dray, S., Chessel, D., Thioulouse, J., 2003. Co-inertia analysis and the linking of ecological data tables. Ecology 84, 3078-3089.

Dray, S., Dufour, A.B., 2007. The ade4 package: Implementing the duality diagram for ecologists. Journal of Statistical Software 22, 1-20.

Everitt, B.S., Landau, S., Leese, M. and, Stahl, D., 2011. Hierarchical Clustering, Cluster An. ed. Chichester, UK. doi:10.1002/9780470977811.ch4

Feng, Q., Zhao, W.W., Fu, B.J., Ding, J.Y., Wang, S., 2017. Ecosystemservice trade-offs and their influencing factors: A case study in the Loess Plateau of China. Sci. Total Environ. 607, 12501263.

Finney, D.M., Murrell, E.G., White, C.M., Baraibar, B., Barbercheck, M.E., Bradley, B.A., Cornelisse, S., Hunter, M.C., Kaye, J.P., Mortensen, D.A., Mullen, C.A., Schipanski, M.E., 2017. Ecosystem Services and Disservices Are Bundled in Simple and Diverse Cover Cropping Systems. Agricultural \& Environmental Letters 2.

Fraga, H., Atauri, I.G.D., Malheiro, A.C., Santos, J.A., 2016. Modelling climate change impacts on viticultural yield, phenology and stress conditions in Europe. Global Change Biol. 22, 3774-3788.

Gaba, S., Lescourret, F., Boudsocq, S., Enjalbert, J., Hinsinger, P., Journet, E.P., Navas, M.L., Wery, J., Louarn, G., Malezieux, E., Pelzer, E., Prudent, M., Ozier-Lafontaine, H., 2015. Multiple cropping systems as drivers for providing multiple ecosystem services: from concepts to design. Agron. Sustain. Dev. 35, 607-623.

Gibert, C., Chadoeuf, J., Nicot, P., Vercambre, G., Genard, M., Lescourret, F., 2009. Modelling the effect of cuticular crack surface area and inoculum density on the probability of nectarine fruit 
infection by Monilinia laxa. Plant Pathol. 58, 1021-1031.

Gilbert, C., Chadoeuf, J., Vercambre, G., Genard, M., Lescourret, F., 2007. Cuticular cracking on nectarine fruit surface: Spatial distribution and development in relation to irrigation and thinning. J. Am. Soc. Hortic. Sci. 132, 583-591.

Grechi, I., Ould-Sidi, M., Hilgert, N., Senoussi, R., Sauphanor, B., Lescourret, F., 2012. Designing integrated management scenarios using simulation-based and multi-objective optimization: Application to the peach tree-Myzus persicae aphid system. Ecol. Modell. 246, 47-59. doi:10.1016/j.ecolmodel.2012.07.023

Groot, J., Rossing, W., 2011. Model-aided learning for adaptive management of natural resources: An evolutionary design perspective. Methods Ecol. Evol. 2, 643-650. doi:10.1111/j.2041210X.2011.00114.x

Grove, G., Eastwell, K., Jones, A., Sutton, T., 2003. Diseases of apple, Apples: botany, production and uses. CABI, Wallingford. doi:10.1079/9780851995922.0000

Guilpart, N., Roux, S., Gary, C., Metay, A., 2017. The trade-off between grape yield and grapevine susceptibility to powdery mildew and grey mould depends on inter-annual variations in water stress. Agric. For. Meteorol. 234, 203-211.

Haines-Young, R., Potschin, M., 2009. Methodologies for defining and assessing ecosystem services. Final Report, JNCC, Proj. Code C08-0170-0062 69 pp.

Heal, G., Small, A., 2002. Agriculture and its External Linkages, in: Gardner, B., Rausser, G. (Eds.), Handbook of Agricultural Economics: Volume 2A, Handbook of Agricultural Economics. Elsevier, Amsterdam, pp. 1342-1369. doi:10.1016/S1574-0072(02)10007-7

Holb, I.J., 2005. Effect of Pruning on Apple Scab in Organic Apple Production. Plant Dis. 89, 611-618. doi:10.1094/PD-89-0611

Kragt, M.E., Robertson, M.J., 2014. Quantifying ecosystem services trade-offs from agricultural 
practices. Ecol. Econ. 102, 147-157. doi:10.1016/j.ecolecon.2014.04.001

Lafond, V., Cordonnier, T., Mao, Z., Courbaud, B., 2017. Trade-offs and synergies between ecosystem services in uneven-aged mountain forests: evidences using Pareto fronts. Eur. J. For. Res. 136, 997-1012.

Laget, E., Guadagnini, M., Plénet, D., Simon, S., Assié, G., Billote, B., Borioli, P., Bourguoin, B., Fratantuono, M., Guérin, A., Hucbourg, B., Lemarquand, A., Loquet, B., Mercadal, M., Parveaud, C., Ramade, L., Rames, M.-H., Ricaud, V., Rousselou, C., Sagnes, J.-L., Zavagli, F., 2015. Guide pour la conception de systèmes de production fruitière économes en produits phytopharmaceutiques. Paris.

Lamy, T., Liss, K.N., Gonzalez, A., Bennett, E.M., 2016. Landscape structure affects the provision of multiple ecosystem services. Environmental Research Letters 11.

Lavorel, S., Grigulis, K., Lamarque, P., Colace, M.P., Garden, D., Girel, J., Pellet, G., Douzet, R., 2011. Using plant functional traits to understand the landscape distribution of multiple ecosystem services. J. Ecol. 99, 135-147.

Lee, H., Lautenbach, S., 2016. A quantitative review of relationships between ecosystem services. Ecol. Indicators 66, 340-351.

Leh, M.D.K., Matlock, M.D., Cummings, E.C., Nalley, L.L., 2013. Quantifying and mapping multiple ecosystem services change in West Africa. Agric. Ecosyst. Environ. 165, 6-18.

Lemaire, G., Gastal, F., 1997. N Uptake and Distribution in Plant Canopies, in: Lemaire, G. (Ed.), Diagnosis of the Nitrogen Status in Crops. Springer Berlin Heidelberg, Berlin, Heidelberg, pp. 343. doi:10.1007/978-3-642-60684-7_1

Lu, N., Fu, B.J., Jin, T.T., Chang, R.Y., 2014. Trade-off analyses of multiple ecosystem services by plantations along a precipitation gradient across Loess Plateau landscapes. Landsc. Ecol. 29, 1697-1708. 
Martin-Lopez, B., Iniesta-Arandia, I., Garcia-Llorente, M., Palomo, I., Casado-Arzuaga, I., Del Amo, D.G., Gomez-Baggethun, E., Oteros-Rozas, E., Palacios-Agundez, I., Willaarts, B., Gonzalez, J.A., Santos-Martin, F., Onaindia, M., Lopez-Santiago, C., Montes, C., 2012. Uncovering Ecosystem Service Bundles through Social Preferences. Plos One 7.

Meacham, M., Queiroz, C., Norstrom, A.V., Peterson, G.D., 2016. Social-ecological drivers of multiple ecosystem services: what variables explain patterns of ecosystem services across the Norrstrom drainage basin? Ecol. Soc. 21.

Meylan, L., Gary, C., Allinne, C., Ortiz, J., Jackson, L., Rapidel, B., 2017. Evaluating the effect of shade trees on provision of ecosystem services in intensively managed coffee plantations. Agric. Ecosyst. Environ. 245, 32-42.

Montanaro, G., Tuzio, A.C., Xylogiannis, E., Kolimenakis, A., Dichio, B., 2017. Carbon budget in a Mediterranean peach orchard under different management practices. Agric. Ecosyst. Environ. 238, 104-113.

Mouchet, M.A., Lamarque, P., Martín-López, B., Crouzat, E., Gos, P., Byczek, C., Lavorel, S., 2014. An interdisciplinary methodological guide for quantifying associations between ecosystem services. Global Environ. Change 28, 298-308.

Murtagh, F., Legendre, P., 2014. Ward's Hierarchical Agglomerative Clustering Method : Which Algorithms Implement Ward 's Criterion ? J. Classif. 31, 274-295. doi:10.1007/s00357-

Nelson, E., Mendoza, G., Regetz, J., Polasky, S., Tallis, H., Cameron, D.R., Chan, K.M.A., Daily, G.C., Goldstein, J., Kareiva, P.M., Lonsdorf, E., Naidoo, R., Ricketts, T.H., Shaw, M.R., 2009. Modeling multiple ecosystem services, biodiversity conservation, commodity production, and tradeoffs at landscape scales. Front. Ecol. Environ. 7, 4-11.

Ould-Sidi, M., Lescourret, F., 2011. Model-based design of integrated production systems: a review. Agron. Sustain. Dev. 31, 571-588. doi:10.1007/s13593-011-0002-8 
Power, A.G., 2010. Ecosystem services and agriculture: tradeoffs and synergies. Philos. Trans. R. Soc. Lond., Ser. B: Biol. Sci. 365, 2959-2971.

Queiroz, C., Meacham, M., Richter, K., Norström, A.V., Andersson, E., Norberg, J., Peterson, G., 2015. Mapping bundles of ecosystem services reveals distinct types of multifunctionality within a Swedish landscape. Ambio 44, 89-101.

Rapidel, B., Ripoche, A., Allinne, C., Metay, A., Deheuvels, O., Lamanda, N., Blazy, J.-M., ValdésGómez, H., Gary, C., 2015. Analysis of ecosystem services trade-offs to design agroecosystems with perennial crops. Agron. Sustain. Dev. 35, 0. doi:10.1007/s13593-015-0317-y

Raudsepp-Hearne, C., Peterson, G.D., Bennett, E.M., 2010. Ecosystem service bundles for analyzing tradeoffs in diverse landscapes. Proc. Natl. Acad. Sci. USA 107, 5242-5247.

Reid, W., Mooney, H., Cropper, A., Capistrano, D., Carpentier, S., Chopra, K., Dasgupta, P., Dietz, T., Duraiappah, A., Hassan, R., Kasperson, R., Leemans, R., May, R., McMichael, A., Pingali, P., Samper, C., Scholes, R., Watson, R., Zakri, A., Shidong, Z., Ash, N., Bennett, J., Kumar, P., Lee, M., Raudsepp-Hearne, C., Simons, H., Thonell, J., Zurek, N., 2005. Ecosystems and Human Wellbeing: Synthesis. Millenium Ecosystem Assessment, Millenium Ecosystem Assessment Synthesis Report. Island Press, Washington DC.

Renard, D., Rhemtulla, J.M., Bennett, E.M., 2015. Historical dynamics in ecosystem service bundles. Proc. Natl. Acad. Sci. U. S. A. 112, 13411-13416.

Ripoche, A., Rellier, J., Martin-Clouaire, R., Paré, N., Biarnès, A., Gary, C., 2011. Modelling adaptive management of intercropping in vineyards to satisfy agronomic and environmental performances under Mediterranean climate. Environ. Model. Softw. 26, 1467-1480. doi:10.1016/j.envsoft.2011.08.003

Robertson, M., Bathgate, A., Moore, A., Lawes, R., Lilley, J., 2009. Seeking simultaneous improvements in farm profit and natural resource indicators: A modelling analysis. Anim. Prod. 
Sci. 49, 826-836. doi:10.1071/AN09008

Rodríguez, J., Beard, T., Bennett, E., Cumming, G., Cork, S., Agard, J., Dobson, A., Peterson, G., 2006. Trade-offs across Space, Time, and Ecosystem Services. Ecol. Soc. 11, 28.

Rousseeuw, P.J., 1987. Silhouettes: A graphical aid to the interpretation and validation of cluster analysis. Journal of Computational and Applied Mathematics 20, 53-65.

Rousselin, A., Bevacqua, D., Vercambre, G., Sauge, M.H., Lescourret, F., Jordan, M.O., 2018. Rosy apple aphid abundance on apple is shaped by vegetative growth and water status. Crop Prot. 105, 1-9.

Sabatier, R., Lebretion, J.D., Chessel, D., 1989. Principal component analysis with instrumental variables as a tool for modeling composition data., in: Coppi, R., Bolasco, S. (Eds. . (Ed.), Multiway Data Analysis. Elsevier Science Publishers, Amsterdam, p. 341.

Saffih-Hdadi, K., Mary, B., 2008. Modeling consequences of straw residues export on soil organic carbon. Soil Biol. Biochem. 40, 594-607. doi:10.1016/j.soilbio.2007.08.022

Sanon, S., Hein, T., Douven, W., Winkler, P., 2012. Quantifying ecosystem service trade-offs: The case of an urban floodplain in Vienna, Austria. J. Environ. Manage. 111, 159-172. doi:10.1016/j.jenvman.2012.06.008

Scandellari, F., Caruso, G., Liguori, G., Meggio, F., Assunta, M.P., Zanotelli, D., Celano, G., Gucci, R., Inglese, P., Pitacco, A., Tagliavini, M., 2016. A survey of carbon sequestration potential of orchards and vineyards in Italy. Eur. J. Hortic. Sci. 81, 106-114.

Schipanski, M.E., Barbercheck, M., Douglas, M.R., Finney, D.M., Haider, K., Kaye, J.P., Kemanian, A.R., Mortensen, D.A., Ryan, M.R., Tooker, J., White, C., 2014. A framework for evaluating ecosystem services provided by cover crops in agroecosystems. Agric. Sys. 125, 12-22.

Seppelt, R., Dormann, C.F., Eppink, F. V, Lautenbach, S., Schmidt, S., 2011. A quantitative review of ecosystem service studies: approaches, shortcomings and the road ahead. J. Appl. Ecol. 48, 
630-636. doi:10.1111/j.1365-2664.2010.01952.x

Seppelt, R., Lautenbach, S., Volk, M., 2013. Identifying trade-offs between ecosystem services, land use, and biodiversity: a plea for combining scenario analysis and optimization on different spatial scales. Curr. Opin. Environ. Sustain. 5, 458-463. doi:10.1016/j.cosust.2013.05.002

Simon, S., Lesueur-Jannoyer, M., Plenet, D., Lauri, P.E., Le Bellec, F., 2017. Methodology to design agroecological orchards: Learnings from on-station and on-farm experiences. Eur. J. Agron. 82, 320-330.

Strullu, L., Beaudoin, N., de Cortàzar Atauri, I.G., Mary, B., 2014. Simulation of Biomass and Nitrogen Dynamics in Perennial Organs and Shoots of Miscanthus $\times$ Giganteus Using the STICS Model. BioEnergy Res. 7, 1253-1269. doi:10.1007/s12155-014-9462-4

Swinton, S., Lupi, F., Robertson, G., Hamilton, S., 2007. Ecosystem services and agriculture: Cultivating agricultural ecosystems for diverse benefits. Ecol. Econ. 64, 245-252. doi:10.1016/j.ecolecon.2007.09.020

Syswerda, S.P., Robertson, G.P., 2014. Ecosystem services along a management gradient in Michigan (USA) cropping systems. Agric. Ecosyst. Environ. 189, 28-35. doi:10.1016/j.agee.2014.03.006

Thioulouse, J., Dray, S., Dufour, A.B., Siberchicot, A., Jombart, T., Pavoine, S., 2018. Multivariate Analysis of Ecological Data with ade4. Springer-Verlag New York.

Turner, K.G., Odgaard, M.V., Bøcher, P.K., Dalgaard, T., Svenning, J.-C., 2014. Bundling ecosystem services in Denmark: Trade-offs and synergies in a cultural landscape. Landsc. Urban Plann. 125, 89-104.

Zanchi, G., Belyazid, S., Akselsson, C., Yu, L., 2014. Modelling the effects of management intensification on multiple forest services: a Swedish case study. Ecol. Model. 284, 48-59.

Zhang, W., Ricketts, T., Kremen, C., Carney, K., Swinton, S., 2007. Ecosystem services and dis-services to agriculture. Ecol. Econ. 64, 253-260. doi:10.1016/j.ecolecon.2007.02.024 


\section{Appendices}

Appendix 1 (Table)

Appendix 2 (Table)

Appendix 3: Boxplots of the impact of irrigation modalities on water comfort $(A)$, carbon sequestrated in the annual organs of trees (B), and N mineralized (C). Abbreviations are defined in Tables 2 and 3.

Appendix 4: Boxplots of the impact of fertilizer type and quantity on the nitrogen absorbed (A), the nitrogen nutrition index (B), the carbon sequestrated in the annual organs of trees $(C)$, and the nitrate leached (D). Abbreviations are defined in Tables 2 and 3.

Appendix 5: Boxplots of the impact of rosy apple aphid control on carbon sequestrated in the annual organs of trees for all cropping systems (A), and for intensively fertilized (i.e., Min140 or Min70) and irrigated (i.e., Com) cropping systems (B). Abbreviations are defined in Tables 2 and 3.

Appendix 6: Correlation plots of explanatory variables, i.e., ecosystem functions (A), and of response variables, i.e., ecosystem services (B), with respect to the first and third PCAIV components, PC1 (xaxis, 51.5\%) and PC3 (y-axis, 8.2\%). Abbreviations are defined in Tables 1 and 2.

Appendix 7: Ecosystem service profiles of the five identified non-dominant cropping systems (CS) on radar plots. CS1 and CS3 have the same profile. CS1 presents the shortest distance to the ideal tradeoff solution. 


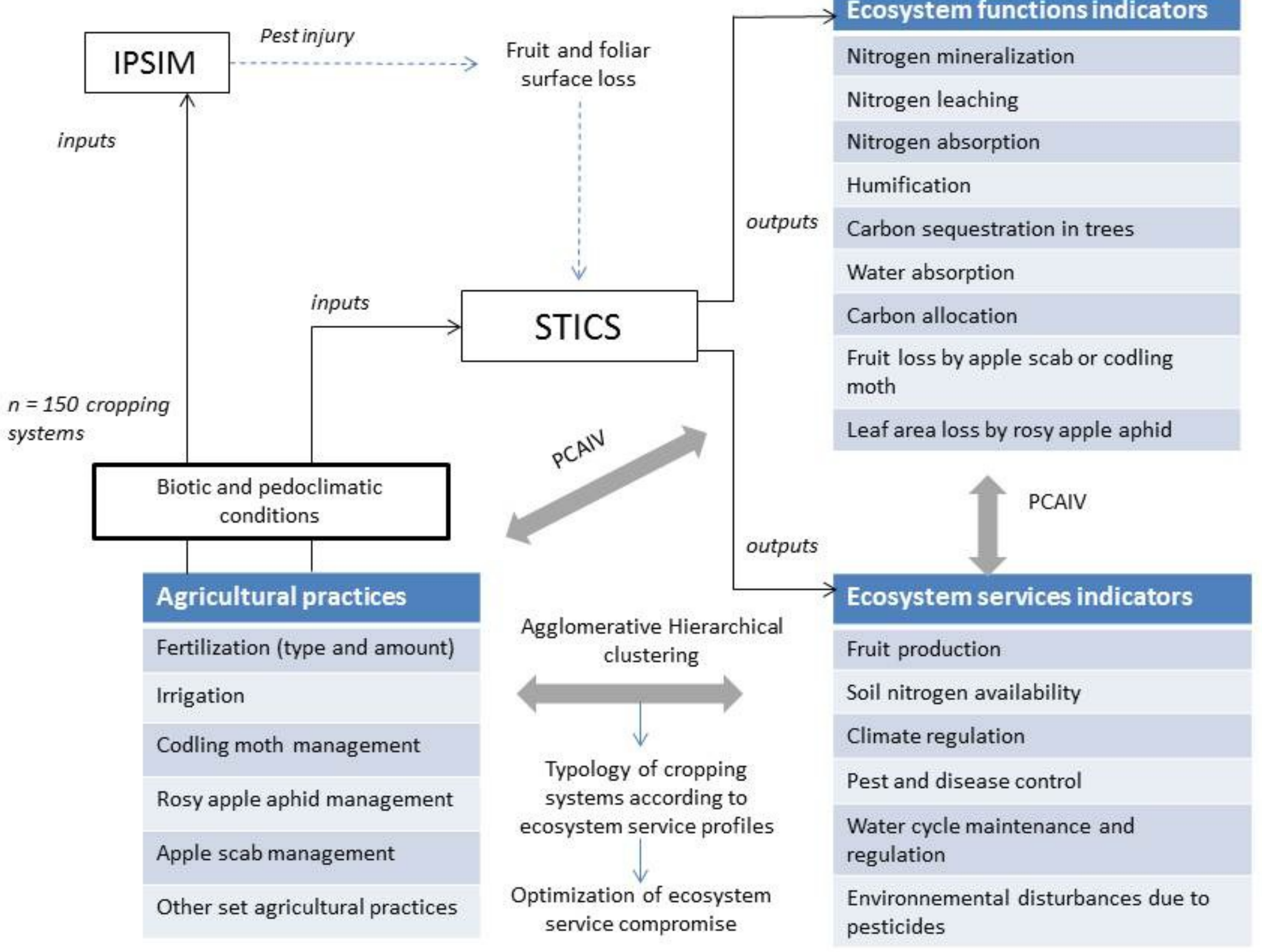


Agricultural practices

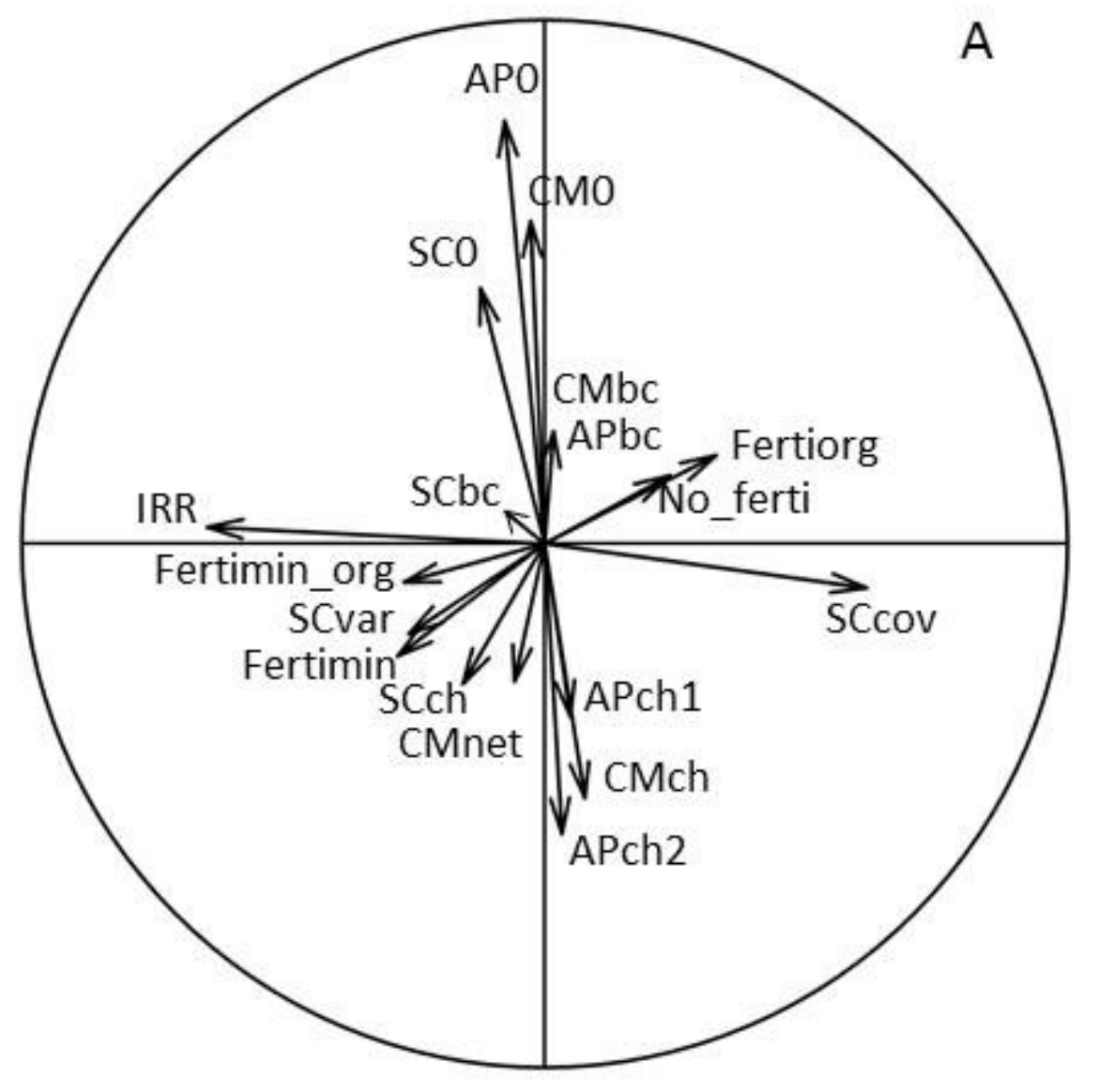

Ecosystem functions

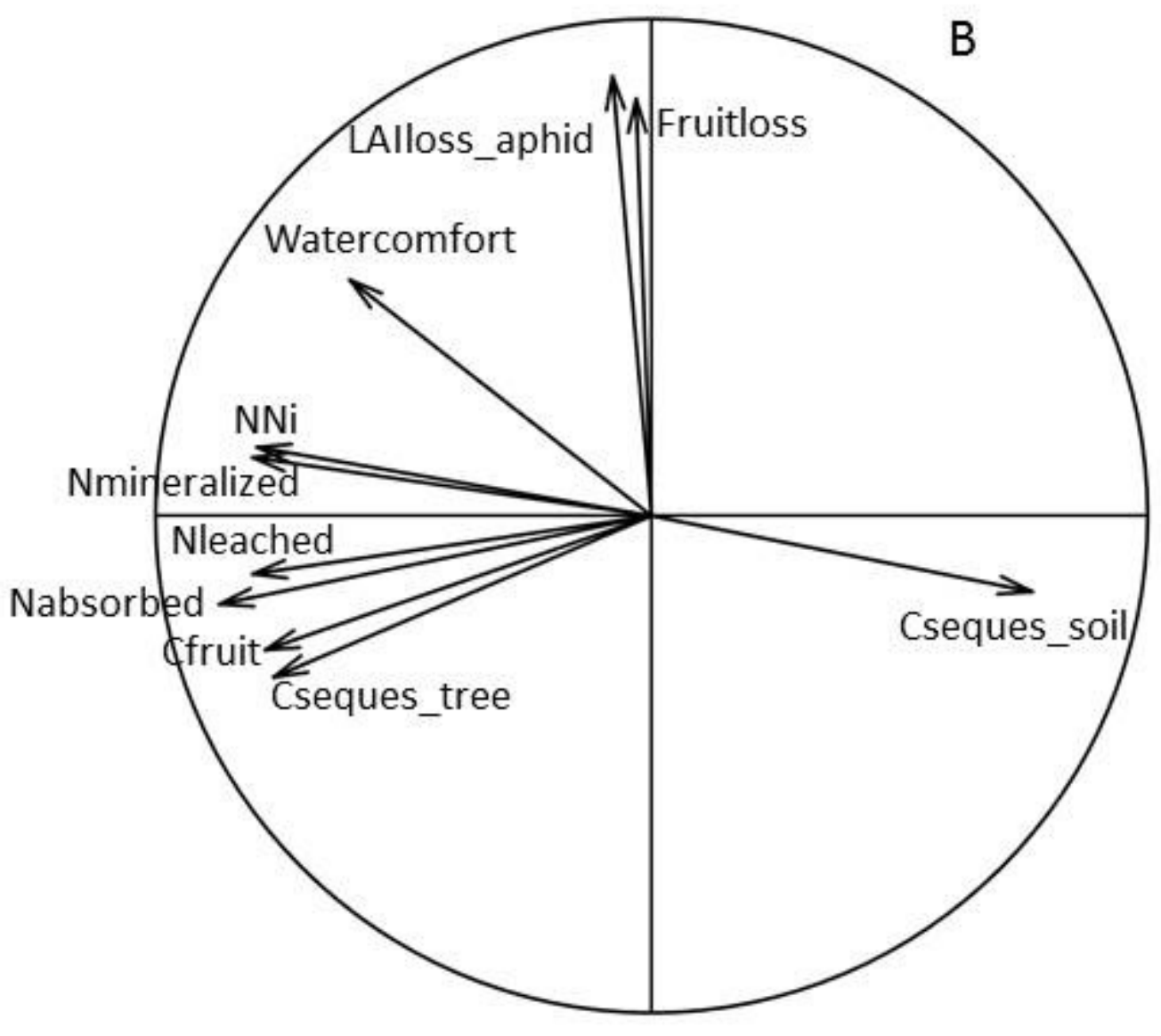


Ecosystem functions

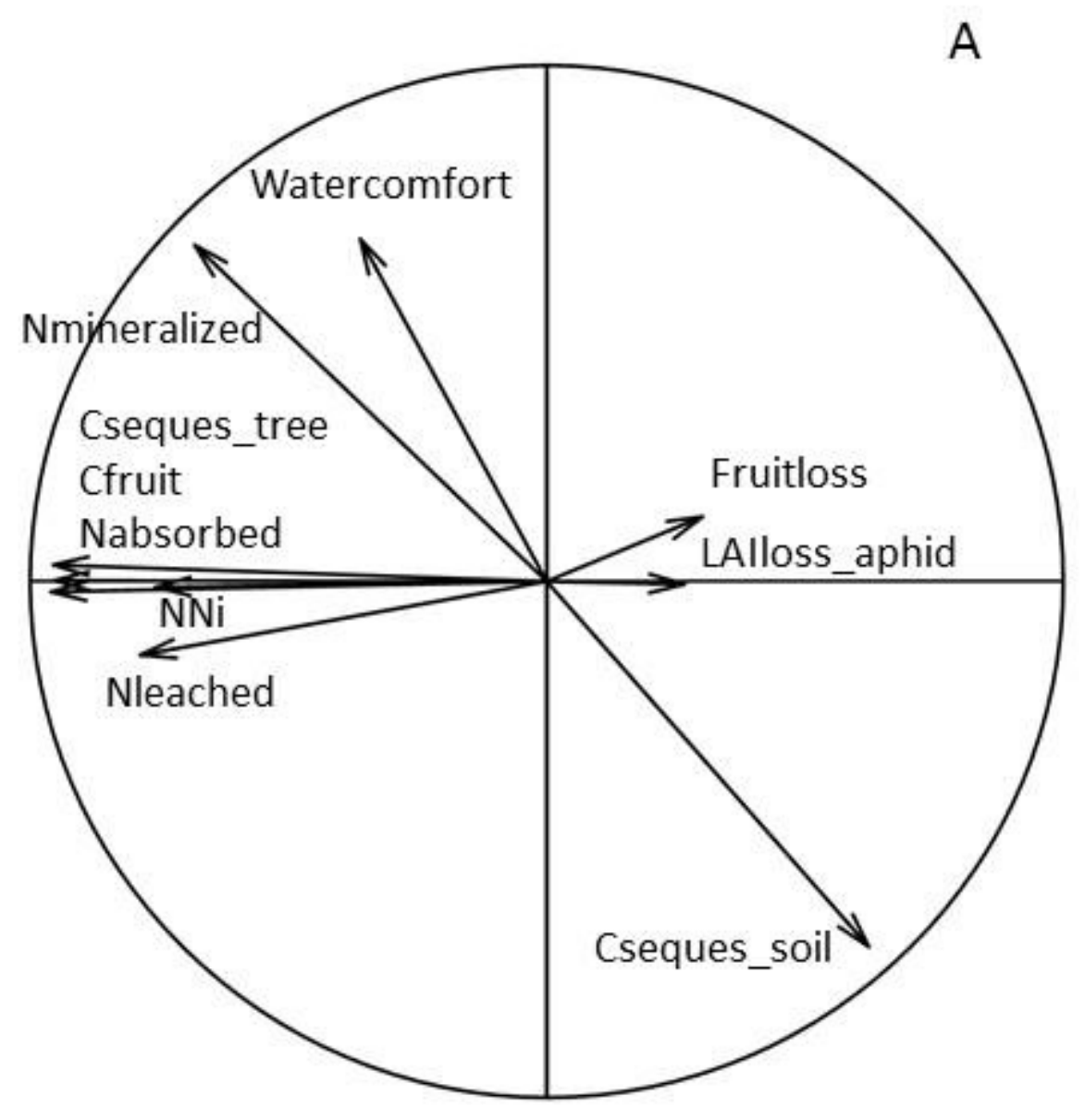

Ecosystem services

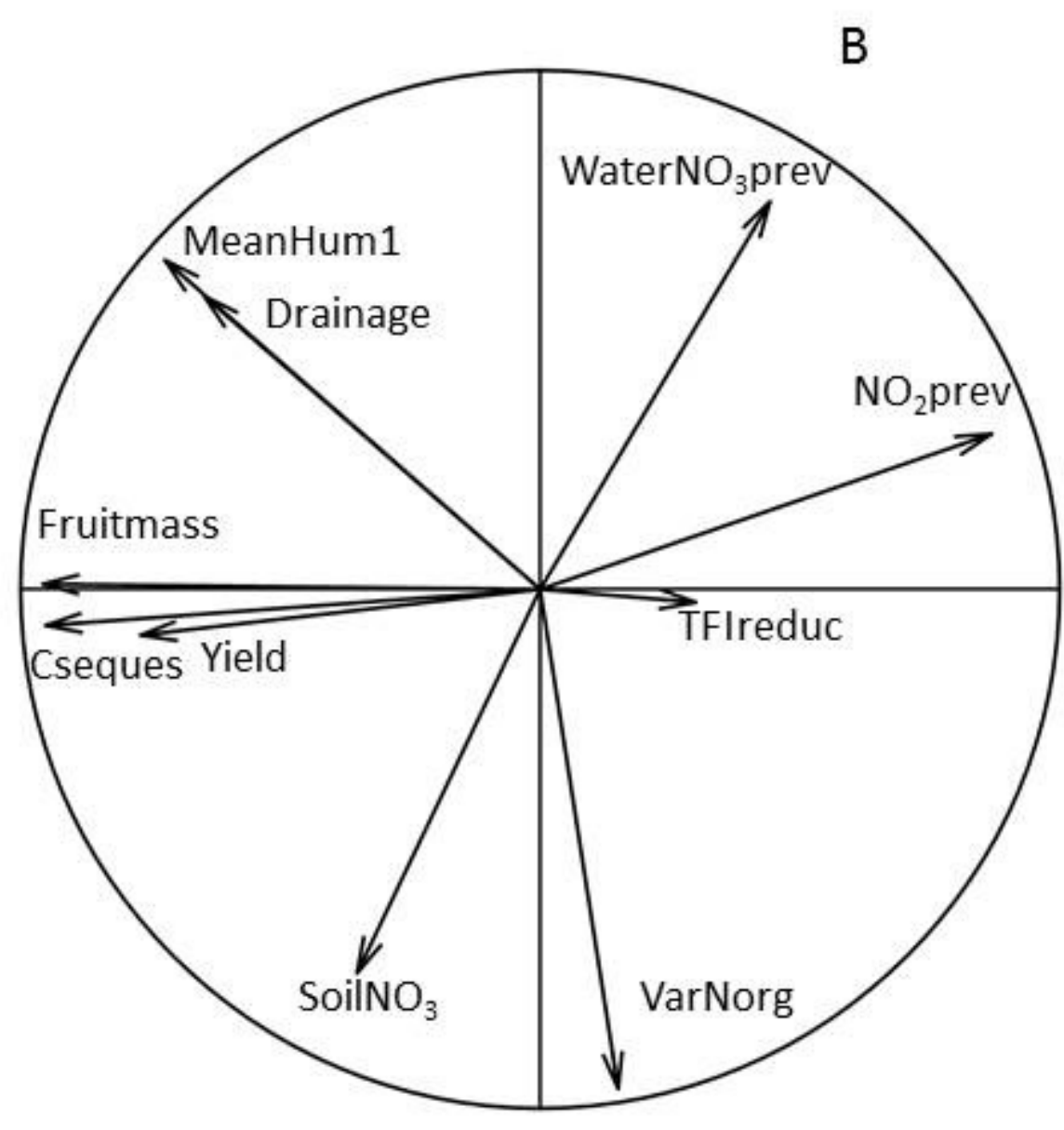



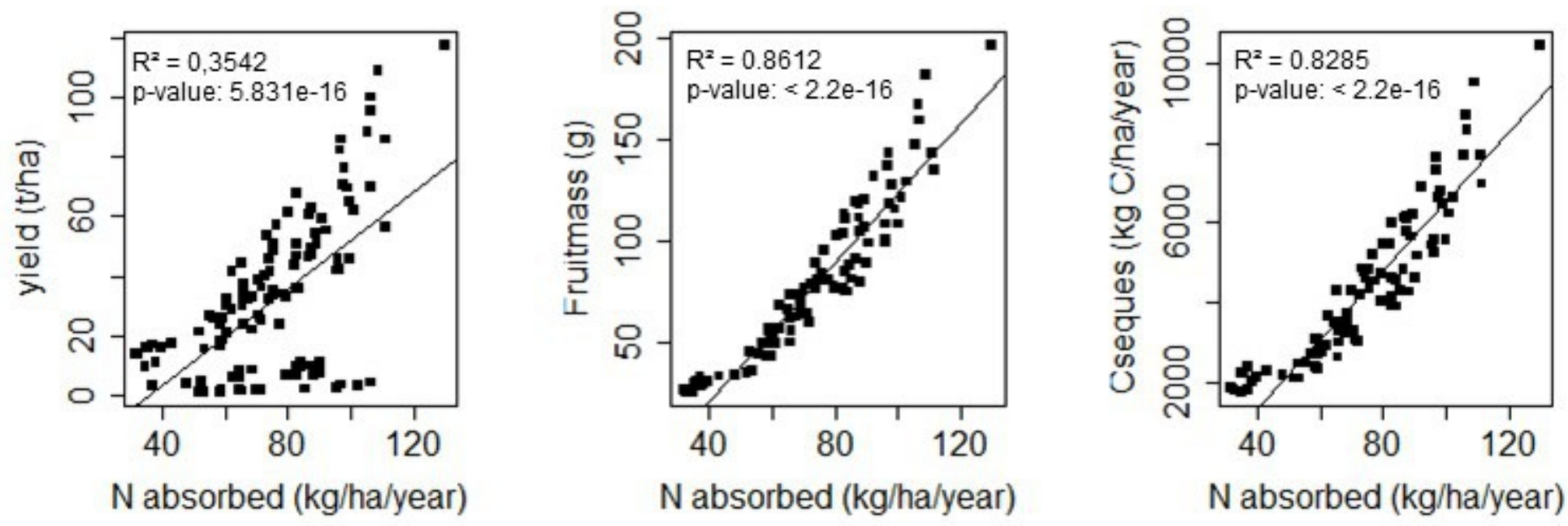


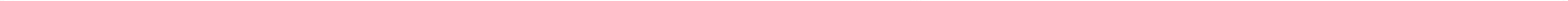



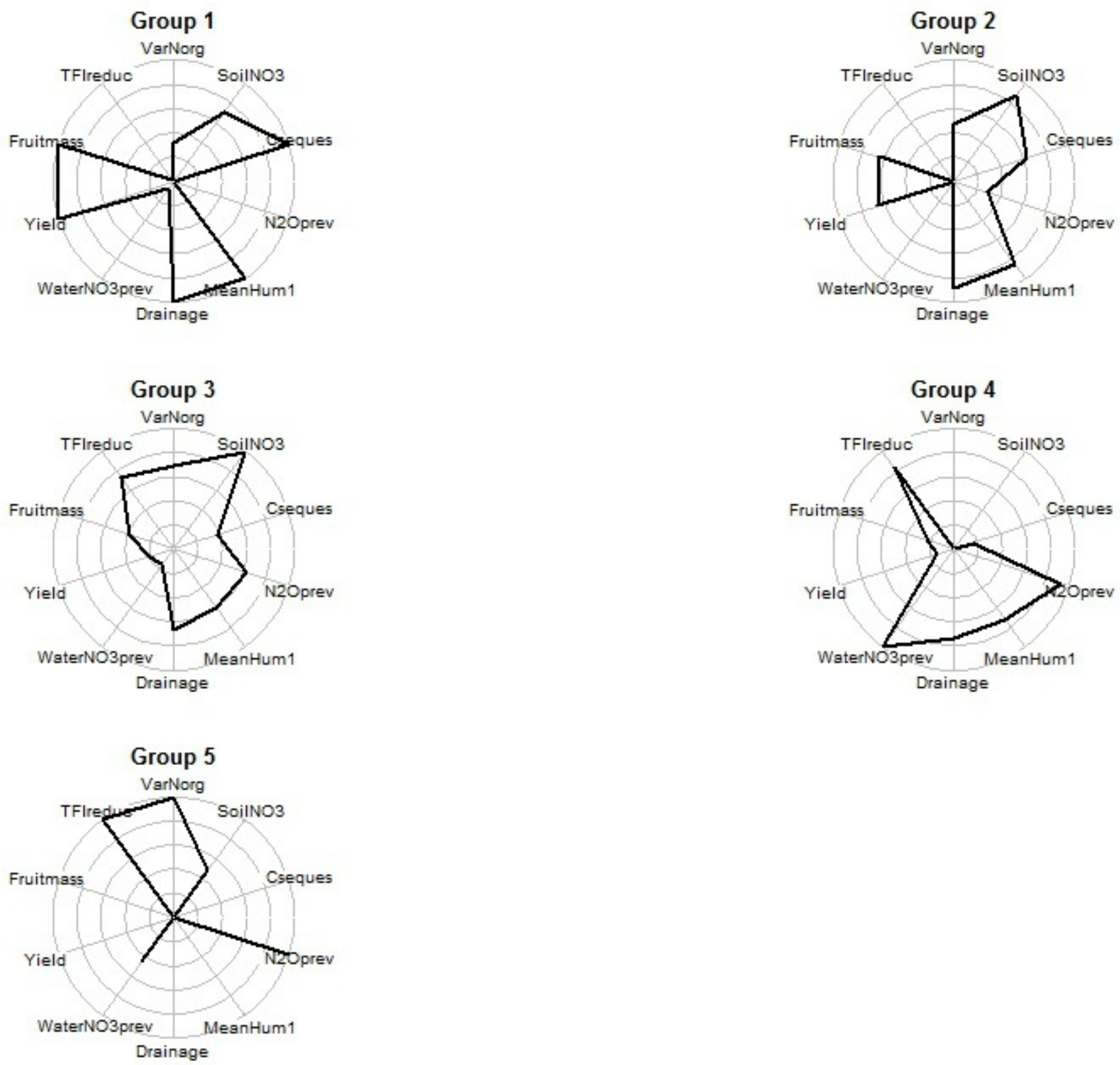


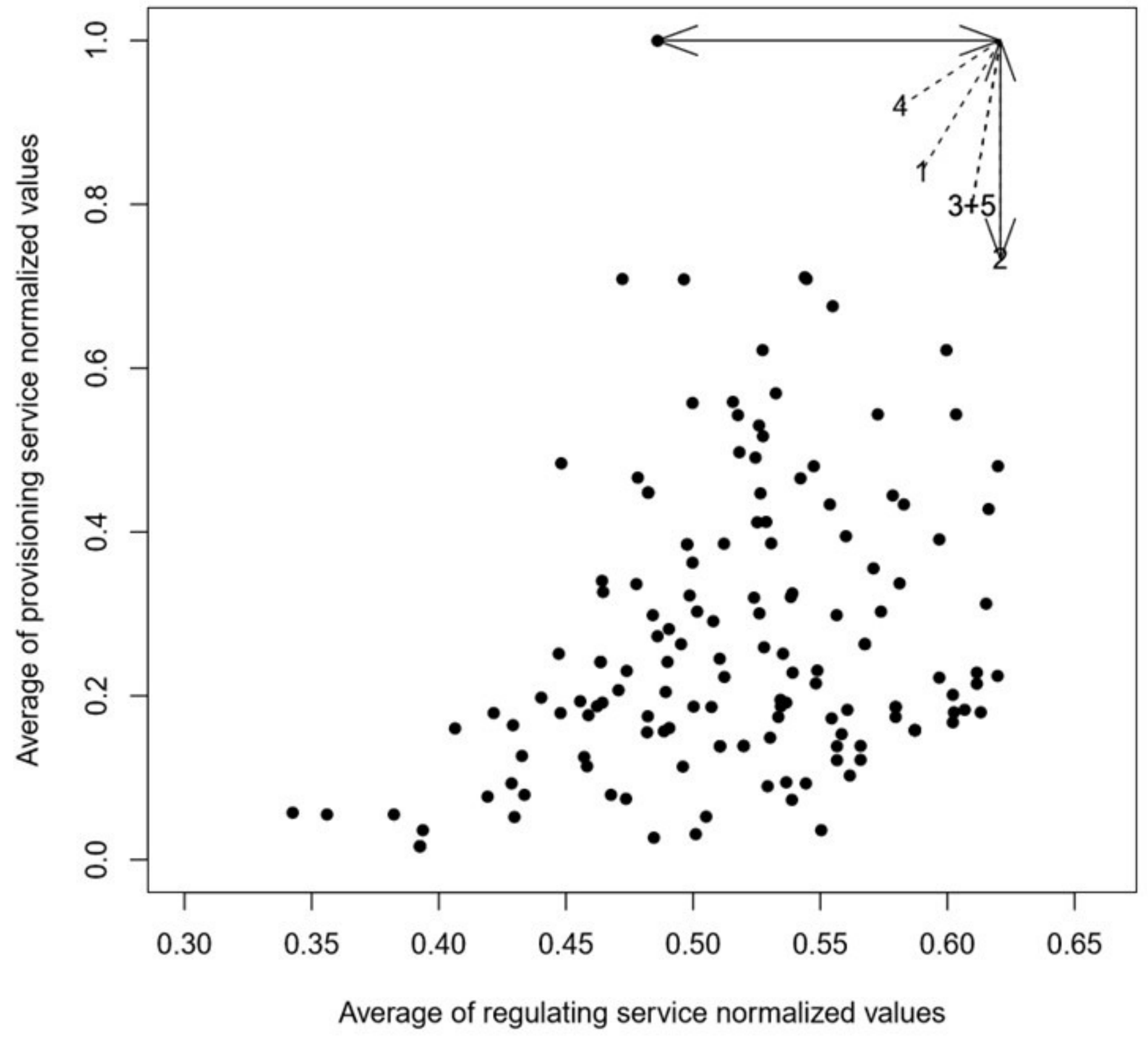


Table 1: Ecosystem service indicators, abbreviated names and units.

\begin{tabular}{|c|c|c|c|}
\hline Service & Indicator & $\begin{array}{l}\text { Abbreviated } \\
\text { name }\end{array}$ & Unit \\
\hline $\begin{array}{l}\text { Soil nitrogen } \\
\text { availability }\end{array}$ & $\begin{array}{l}\text { Yearly variation of organic } \\
\text { nitrogen } \\
\text { Mean nitrate concentration } \\
\text { in } 0-30 \mathrm{~cm} \text { soil layer }\end{array}$ & $\begin{array}{l}\text { VarNorg } \\
\text { SoilNO }_{3}\end{array}$ & $\begin{array}{l}\text { kg N ha-1 } \text { year }^{-1} \\
{\mathrm{mg} \mathrm{N}-\mathrm{NO}_{3}}_{\mathrm{kg} \text { of dry soil }}{ }^{-1}\end{array}$ \\
\hline $\begin{array}{l}\text { Climate } \\
\text { regulation }\end{array}$ & $\begin{array}{l}\text { Prevention of nitrogen } \\
\text { denitrification } \\
\text { Quantities of carbon fixed in } \\
\text { the soil and in the annual } \\
\text { organs of the tree }\end{array}$ & Cseques & kg C ha-1 year $^{-1}$ \\
\hline $\begin{array}{l}\text { Water cycle } \\
\text { maintenance and } \\
\text { regulation }\end{array}$ & $\begin{array}{l}\text { Mean soil humidity in 0-30 } \\
\text { cm soil layer } \\
\text { Water drainage } \\
\text { Nitrate leaching prevention }\end{array}$ & Drainage & $\begin{array}{l}\mathrm{mm} \mathrm{year}^{-1} \\
\mathrm{mg} \mathrm{NO}_{3} \text { I of drained } \\
\text { water }{ }^{-1}\end{array}$ \\
\hline Fruit production & $\begin{array}{l}\text { Yield } \\
\text { Mean fresh fruit mass } \\
\text { (quality criterion for the } \\
\text { market) }\end{array}$ & $\begin{array}{l}\text { Yield } \\
\text { Fruitmass }\end{array}$ & $\begin{array}{l}\text { t ha }^{-1} \\
g\end{array}$ \\
\hline
\end{tabular}




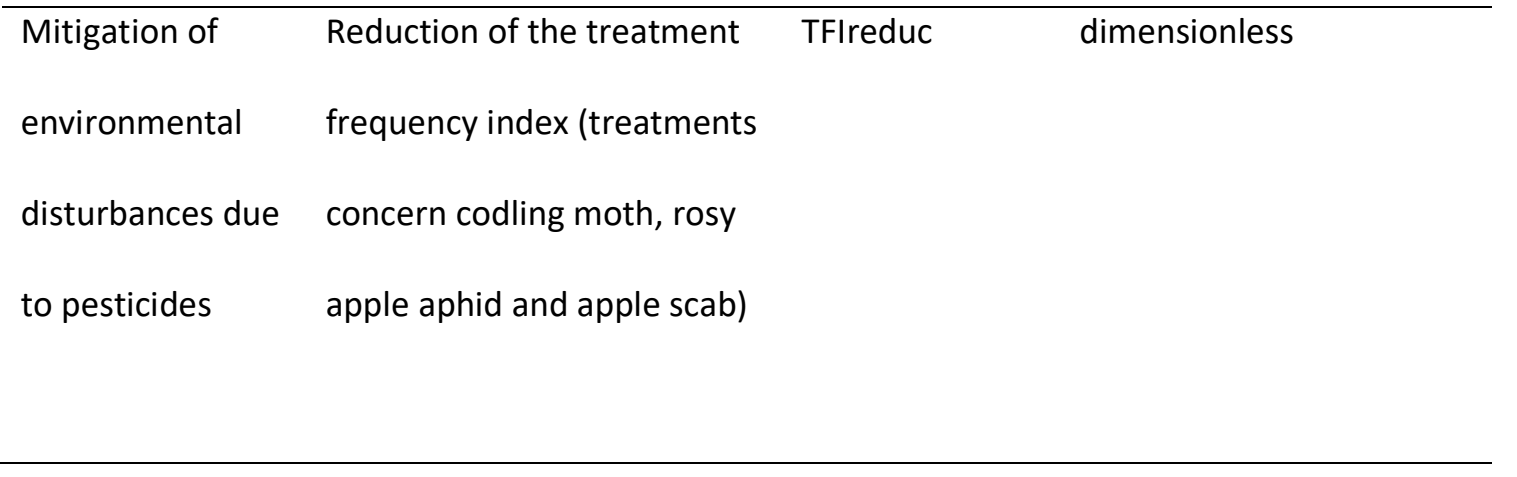


Table 2: Ecosystem function indicators, abbreviated names and units.

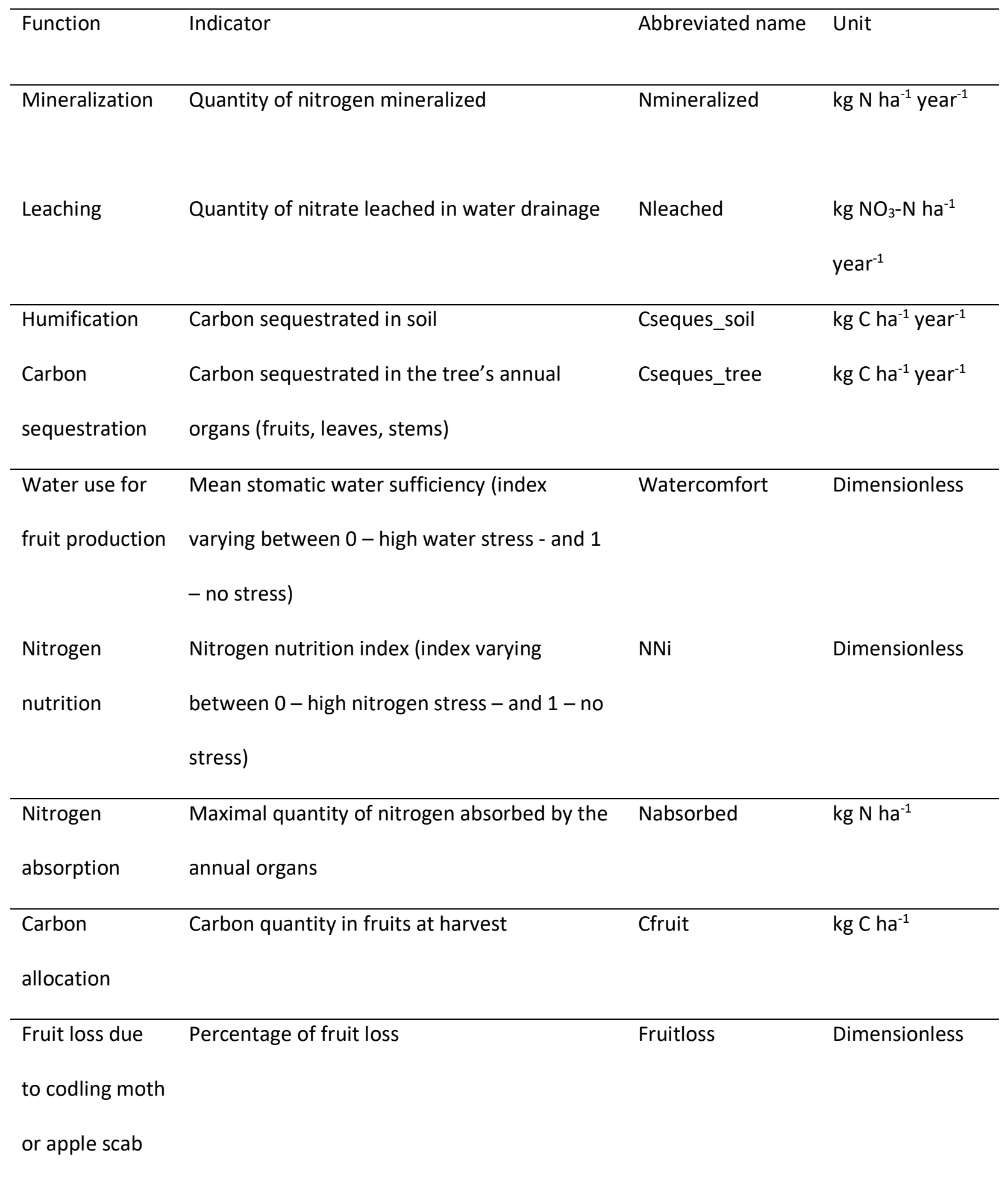


loss due to rosy Fraction of daily leaf area loss

apple aphid 
Table 3 : Agricultural practices and their modalities. Each practice or modality is described by an abbreviated name. Regarding pest control, 'bc' means biocontrol and ' $c h$ ' means chemical.

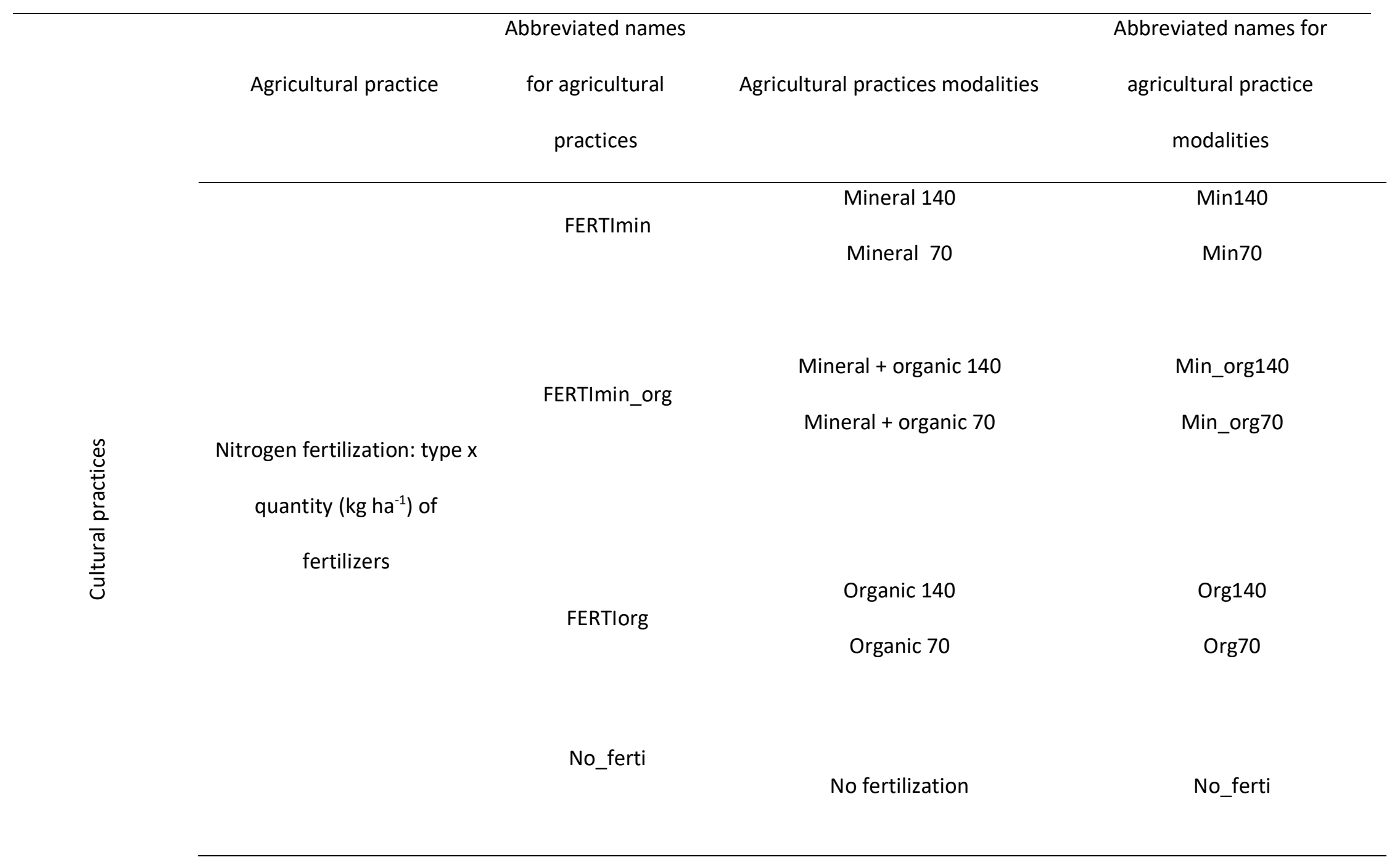




\begin{tabular}{|c|c|c|c|}
\hline \multirow{4}{*}{ Irrigation: water input level } & \multirow{4}{*}{ IRRI } & Comfort & Com \\
\hline & & Low water stress & LWS \\
\hline & & High water stress & HWS \\
\hline & & No irrigation & No_irrig \\
\hline \multirow{6}{*}{ Codling moth control } & \multirow{6}{*}{$\mathrm{CM}$} & Exclusion nets & CMnet \\
\hline & & Granulovirus + mating disruption & $\mathrm{CMbc}$ \\
\hline & & Chemical pesticides + mating & \\
\hline & & & CMch \\
\hline & & disruption & \\
\hline & & No control & $\mathrm{CMO}$ \\
\hline \multirow{5}{*}{ Rosy apple aphid control } & \multirow{4}{*}{ AP } & Oil and/or clay applications & $\mathrm{APbc}$ \\
\hline & & Oil + chemical pesticides & APch1 \\
\hline & & Chemical pesticides & APch2 \\
\hline & & No control & APO \\
\hline & SC & Chemical fungicides & SCch \\
\hline
\end{tabular}


Sulfur and copper (products

authorized in organic agriculture)

$\mathrm{SCbc}$

Apple scab control

Resistant variety

SCvar

Rain-proof cover

SCcov

No control 
Table 4: Absolute frequencies of the modalities of the agricultural practices within the five groups of virtual orchard cropping systems. Values in bold indicate the dominant practice used in each group. Abbreviations are defined in Table 3.

\begin{tabular}{|c|c|c|c|c|c|c|}
\hline & & Group 1 & Group 2 & Group 3 & Group4 & Group5 \\
\hline \multirow[t]{7}{*}{ Fertilization } & Min140 & 0.14 & 0.32 & 0.24 & 0.00 & 0.13 \\
\hline & Min70 & 0.43 & 0.18 & 0.27 & 0.00 & 0.04 \\
\hline & Min_org140 & 0.43 & 0.18 & 0.27 & 0.00 & 0.09 \\
\hline & Min_org70 & 0.00 & 0.32 & 0.22 & 0.00 & 0.04 \\
\hline & Org140 & 0.00 & 0.00 & 0.00 & 0.23 & 0.22 \\
\hline & Org70 & 0.00 & 0.00 & 0.00 & 0.33 & 0.26 \\
\hline & No_ferti & 0.00 & 0.00 & 0.00 & 0.44 & 0.22 \\
\hline \multirow[t]{4}{*}{ Irrigation } & Com & 0.57 & 0.36 & 0.14 & 0.29 & 0.00 \\
\hline & LWS & 0.43 & 0.36 & 0.14 & 0.31 & 0.04 \\
\hline & HWS & 0.00 & 0.29 & 0.24 & 0.23 & 0.39 \\
\hline & No_irri & 0.00 & 0.00 & 0.49 & 0.16 & 0.57 \\
\hline \multirow{3}{*}{ Codling moth } & CMnet & 0.29 & 0.50 & 0.35 & 0.41 & 0.22 \\
\hline & & & & & & \\
\hline & CMch & 0.50 & 0.25 & 0.16 & 0.19 & 0.39 \\
\hline \multicolumn{7}{|l|}{ control } \\
\hline & $\mathrm{CMbc}$ & 0.00 & 0.18 & 0.14 & 0.19 & 0.09 \\
\hline & CMO & 0.21 & 0.07 & 0.35 & 0.21 & 0.30 \\
\hline \multirow{3}{*}{ Rosy apple aphid } & APch1 & 0.43 & 0.32 & 0.14 & 0.27 & 0.31 \\
\hline & & & & & & \\
\hline & APch2 & 0.57 & 0.21 & 0.11 & 0.21 & 0.35 \\
\hline \multicolumn{7}{|l|}{ control } \\
\hline & $\mathrm{APbc}$ & 0.00 & 0.46 & 0.30 & 0.25 & 0.17 \\
\hline & APO & 0.00 & 0.00 & 0.46 & 0.27 & 0.17 \\
\hline
\end{tabular}




\begin{tabular}{rrrrrrr} 
SCch & 0.21 & $\mathbf{0 . 3 2}$ & $\mathbf{0 . 2 7}$ & 0.17 & 0.09 \\
Apple scab control & SCbc & 0.07 & 0.29 & $\mathbf{0 . 2 7}$ & $\mathbf{0 . 2 7}$ & 0.13 \\
& SCO & 0.21 & 0.07 & 0.08 & $\mathbf{0 . 2 3}$ & 0.13 \\
SCvar & $\mathbf{0 . 5 0}$ & 0.21 & 0.19 & 0.14 & 0.04 \\
& SCcov & 0.00 & 0.11 & 0.19 & 0.19 & $\mathbf{0 . 6 1}$ \\
\hline
\end{tabular}


Table 5: Mean values (non-normalized) and standard errors of ecosystem service indicators for each of the five groups of cropping systems. The definitions and units of the abbreviations are given in Table 1.

\begin{tabular}{cccccc}
\hline & Group 1 & Group 2 & Group 3 & Group 4 & Group 5 \\
\hline Number of cropping & 14 & 28 & 37 & 48 & 23 \\
systems & & & & $-61.39 \pm 4.80$ \\
\hline VarNorg & $-83.72 \pm 1.88$ & $-78.66 \pm 2.27$ & $-71.40 \pm 2.13$ & $-94.35 \pm 0.81$ & $11.18 \pm 1.56$ \\
SoilNO3 & $13.09 \pm 0.66$ & $14.54 \pm 0.93$ & $15.51 \pm 0.85$ & $7.23 \pm 0.03$ & $2148 \pm 50$ \\
Cseques & $8263 \pm 241$ & $5993 \pm 103$ & $4444 \pm 46$ & $3201 \pm 45$ & $-0.20 \pm 0.02$ \\
N2Oprev & $-0.87 \pm 0.03$ & $-0.67 \pm 0.04$ & $-0.44 \pm 0.03$ & $-0.25 \pm 0.17$ & $17.45 \pm 0.33$ \\
MeanHum1 & $20.77 \pm 0.09$ & $20.26 \pm 0.08$ & $19.45 \pm 0.09$ & $19.85 \pm 0.08$ & $86.69 \pm 5.95$ \\
Drainage & $145 \pm 2.47$ & $138 \pm 3.17$ & $125 \pm 2.98$ & $129 \pm 2.70$ & $-36.27 \pm 1.00$ \\
WaterNO ${ }_{3}$ prev & $-40.70 \pm 1.73$ & $-41.49 \pm 2.03$ & $-39.64 \pm 1.03$ & $-29.68 \pm 0.15$ \\
Yield & $73.46 \pm 10.6$ & $52.58 \pm 3.27$ & $24.64 \pm 2.90$ & $21.04 \pm 1.84$ & $12.41 \pm 1.64$ \\
Fruitmass & $157 \pm 4.72$ & $113 \pm 2.04$ & $81 \pm 0.77$ & $60.89 \pm 0.95$ & $34.64 \pm 1.68$ \\
TFlreduc & $-8.00 \pm 1.62$ & $-8.04 \pm 1.08$ & $-6.11 \pm 0.94$ & $-5.85 \pm 0.76$ & $-5.43 \pm 1.24$ \\
\hline
\end{tabular}

